\title{
1 Chemical denudation and the role of sulfide oxidation at Werenskioldbreen, Svalbard
}

2

3 Lukasz Stachnik ${ }^{\mathrm{a}, \mathrm{b}, *}$, Elżbieta Majchrowska ${ }^{\mathrm{c}}$, Jacob C. Yde $^{\mathrm{b}}$, Adam P. Nawrot $^{\mathrm{d}, \mathrm{e}}$, Katarzyna

4 Cichała-Kamrowska $^{\mathrm{f}}$, Dariusz Ignatiuk $^{\mathrm{c}}$, Agnieszka Piechota $^{\mathrm{c}}$

$5 \quad$ a Institute of Geography and Spatial Management, Jagiellonian University, Kraków, Poland

$6 \quad{ }^{\mathrm{b}}$ Sogn og Fjordane University College, Sogndal, Norway

$7 \quad{ }^{\mathrm{c}}$ Centre for Polar Studies KNOW (Leading National Research Centre), Faculty of Earth

8 Sciences, University of Silesia, Poland

9 Institute of Geophysics Polish Academy of Sciences, Warszawa, Poland

$10{ }^{\mathrm{e}}$ forScience Foundation, Gdańsk, Poland

11 f Department of Analytical Chemistry, The Chemical Faculty, Gdańsk University of

12 Technology, Gdańsk, Poland

13

14 *corresponding author, 1.stachnik@uj.edu.pl, 0044-7598777214, Gronostajowa 7 str., 30-387

15 Kraków, Poland

16

17 
Abstract

This study aims to determine the rate of chemical denudation and the relationships between dominant geochemical reactions operating in the proglacial and subglacial environments of the polythermal glacier Werenskioldbreen (SW Svalbard) during an entire ablation season. Water sampling for major ion chemistry was performed at a proglacial hydrometric station and from subglacial outflows from May to September 2011. These data were combined with measurements of discharge and supraglacial ablation rates. The slopes and intercepts in bestfit regressions of $\left[* \mathrm{Ca}^{2+}+* \mathrm{Mg}^{2+}\right.$ vs. $\left.{ }^{*} \mathrm{SO}_{4}{ }^{2-}\right]$ and $\left[\mathrm{HCO}_{3}{ }^{-}\right.$vs. $\left.{ }^{*} \mathrm{SO}_{4}{ }^{2-}\right]$ in meltwater from icemarginal subglacial channels were close to the stoichiometric parameters of sulfide oxidation and simple hydrolysis coupled to carbonate dissolution $(*$ concentrations corrected for input of sea-salt). This shows that these relationships predominates the meltwater chemistry. Our findings also show that sulfide oxidation is a better indicator of the configuration of subglacial drainage systems than, for instance, $\mathrm{Na}^{+}$and $\mathrm{K}^{+}$. In the proglacial area and in sub-artesian outflows, the ion associations represent sulfide oxidation but other processes such as ion exchange and dissolution of $\mathrm{Ca}$ and $\mathrm{Mg}$ efflorescent salts may also contribute to the solute variations. These processes may cause enhanced fluxes of $\mathrm{Ca}^{2+}$ and $\mathrm{HCO}_{3}{ }^{-}$from glacierised basins during the early ablation and peak flow seasons as the proglacial salts re-dissolve. The overall chemical denudation rate in the basin for 2011 (ranging from 1601 and $1762 \mathrm{meq} \mathrm{m}^{-2}$ $\mathrm{yr}^{-1}\left(121.9\right.$ and $\left.\left.132.2 \mathrm{t} \mathrm{km}^{-2} \mathrm{yr}^{-1}\right)\right)$ was very high when compared to other Svalbard valley glaciers suggesting that the high rate of chemical denudation was mostly caused by the high rates of discharge and ablation. Chemical weathering intensities ( 876 and $964 \mathrm{meq} \mathrm{m}^{-3} \mathrm{yr}^{-1}$ ) exceeded previously reported intensities in Svalbard.

Keywords: Werenskioldbreen; sulfide oxidation; simple hydrolysis; carbonation; runoff; Spitsbergen. 


\section{Introduction}

Glacierised basins affect regional elemental cycles through weathering processes operating in subglacial and proglacial environments (Gíslason et al., 1996; Hodson et al., 2000; Hawkings et al., 2014; Yde et al., 2014). However, there is a general lack of knowledge of the coupling between geochemical reactions in subglacial and proglacial environments and how these reactions change throughout the ablation season.

Reactions that donate $\mathrm{H}^{+}$from the dissociation of organic and inorganic acids are particularly crucial for chemical weathering processes in these and other systems (e.g. Appelo and Postma, 2005), and in glacierised basins, $\mathrm{H}^{+}$ions are primarily derived from the dissociation of inorganic acids such as sulfuric, carbonic or nitric acids (Tranter et al., 1993) or simple hydrolysis (dissociation of $\mathrm{H}^{+}$from water, Tranter et al., 2002; Yde et al., 2005). While simple hydrolysis only dominates during the early phase of contact between water and minerals (Tranter and Wadham, 2013), sulfide oxidation and carbonation dominate in later phases and are the two main acid forming reactions which often are responsible for chemical weathering in glacierised catchments (Brown, 2002; Tranter et al., 2002). Sulfide oxidation in particular, which is usually coupled to the dissolution of carbonates and silicates, is potentially important in supporting primary productivity in oceans due to the delivery of iron (oxyhydr)oxide to ocean waters (Raiswell et al., 2006; Hawkings et al., 2014). Based on ${ }^{34} \mathrm{~S}$ $\mathrm{SO}_{4}{ }^{2-}$ isotope concentrations (Wadham et al., 2004) and slope coefficients in regression equations (Tranter et al., 2002) and geochemical modelling (Mitchell and Brown, 2008), sulfide oxidation is a dominant geochemical control in many glacierised basins consisting of various rock types. For example, pyrite and Fe-bearing oxides in bedrock may fertilize subglacial biogeochemical processes (Mitchell et al., 2013), while the bulk mineralogy of 
bedrock appears to play a second-order effect on chemical weathering in glacierised catchments (Wadham et al., 2010b).

Several studies proposing that carbonation dominates chemical weathering reactions in glacierised catchments rely on interpretations of major ions partitioned by chemical mass balance stoichiometry (Sharp et al., 1995; Hodson et al., 2000; Hindshaw et al., 2011). However, the relative importance of carbonation or sulfide oxidation as major $\mathrm{H}+$ donating processes vary widely in glacierised basins and is often related to small differences in lithology (Singh and Hasnain, 2002; Krawczyk and Bartoszewski, 2008; Wadham et al., 2010a). It is worth noting that some of these studies do not include simple hydrolysis in reaction balancing (Hodson et al., 2000; Krawczyk et al., 2003; Krawczyk and Bartoszewski, 2008). Furthermore, chemical weathering in glacierised basins depends on many other factors such as organic matter content, microbial processes, groundwater input, precipitation and snowpack chemistry (e.g. Mitchell and Brown, 2008), all of which affect $\mathrm{H}^{+}$donating reactions.

In basins with valley-type glaciers, chemical weathering is mainly influenced by bulk meltwater production and seasonal evolution of the subglacial drainage system. During the early ablation season, differential leaching of snowpack-derived solutes (mainly $\mathrm{Na}^{+}, \mathrm{Cl}^{-}$) dominates the chemical composition of the bulk meltwater and the contribution of solute from geochemical weathering processes is low (Wadham et al., 2000; Yde et al., 2008; Stachnik and Uzarowicz, 2011; Stachnik et al., 2014). At this time of year, subglacial conduits may be blocked by ice or snow dams, preventing them from draining the glacier efficiently (IrvineFynn et al., 2011). The breaking of these dams in combination with increased surface ablation causes the occurrence of an early discharge peak during the early ablation season (Brown, 2002). As the ablation season progresses a more effective channelized drainage system is developed, and the relative contribution from less efficient distributed subglacial drainage 
systems with long water residence time diminishes (Irvine-Fynn et al., 2011). When the surface melt rate slows down during the late ablation season, the distributed subglacial drainage system again plays a more important role in recharging the subglacial channels (Nienow et al., 1998; Nowak and Hodson, 2014). In channelized (transport-dominated) systems, carbonation of carbonates and silicates generally predominates, whereas processes such as sulfide oxidation and organic carbon oxidation coupled to dissolution of silicates and carbonates are more important in distributed (weathering-dominated) systems (Tranter et al., 2002). This difference becomes evident during the late ablation season, where an increase in $\mathrm{SO}_{4}{ }^{2-}$ compared to $\mathrm{HCO}_{3}{ }^{-}$has been attributed to sulfide oxidation coupled to carbonate or silicate dissolution in distributed systems (Wadham et al., 1998; Wadham et al., 2010b). When glacial meltwater chemistry in the proglacial zone is compared to the chemical characteristics of subglacial outflows, the observed solute enrichment can be tied to biogeochemical processes operating in proglacial groundwater or in open channels (Cooper et al., 2002; Kristiansen et al., 2013). In the proglacial zone, biogeochemical processes are enhanced by the long residence time of near-surface water, slow groundwater flow, exposure of fresh rock surfaces due to glacier recession and high microbiological activity (Fairchild et al., 1999; Cooper et al., 2002; Bernasconi et al., 2011; Nowak and Hodson, 2014). Expanding vegetation cover provides organic acids and $\mathrm{CO}_{2}$ from the oxidation of organic carbon, and this process subsequently facilitates chemical weathering (Egli et al., 2001; Kabala and Zapart, 2012; Vilmundardóttir et al., 2014). This may lead to an increase in solute fluxes of major ions $\left(\mathrm{Ca}^{2+}, \mathrm{Mg}^{2+}, \mathrm{HCO}_{3}{ }^{-}, \mathrm{SO}_{4}{ }^{2-}\right)$ along proglacial transects (Wadham et al., 2001) and to an enhancement of chemical weathering of silicates (Mavris et al., 2012; Anderson 2006; Vilmundardóttir et al., 2014). Previous studies have shown that glacier forelands may account for 3-4 times more chemical denudation than the glacierised parts of basins (Anderson et al., 2000; Wadham et al., 2001). 
Both oxic and anoxic sulfide oxidation coupled to carbonate and silicate dissolution have been observed in subglacial and proglacial zones (Cooper et al., 2002; Wadham et al., 2004; Wadham et al., 2007). The carbonation of both carbonates and silicates is likely to occur in both systems, but in the subglacial distributed system and in groundwater in the proglacial zone carbonation reactions may be related to microbial respiration processes (Tranter et al., 2002; Bernasconi et al., 2011), whereas the carbonation by atmospheric $\mathrm{CO}_{2}$ sequestration occurs in open channels (Hodson et al., 2002). Sulfate reduction is recognised as a process observed exclusively in anoxic subglacial conditions (Wadham et al., 2007), whereas the dissolution of $\mathrm{Ca}-\mathrm{Mg}$ sulfate, re-dissolution of precipitated calcite, $\mathrm{CO}_{2}$ degassing during calcite precipitation and oxidation of organic carbon are geochemical processes operating in the oxygen-rich proglacial zone (Cooper et al., 2002; Bernasconi et al., 2011; Rutter et al., 2011; Vilmundardóttir et al., 2014). The effectiveness of silicate weathering in the proglacial area is still subject to debate as some studies indicate that an enhancement of the silicate weathering rate does occur (Anderson et al., 2000; Egli et al., 2001; Mavris et al., 2012; Kristiansen et al., 2013), whereas other studies neglect it (Wadham et al., 2001). This study focuses on the characteristics and differences between chemical processes in subglacial and proglacial zones of the glacierised basin of Werenskioldbreen in Spitsbergen, High Arctic. First, we examine seasonal variations in the chemical processes throughout an entire ablation season and relate these to snow and ice ablation rates in the basin in relation to both the subglacial and proglacial drainage systems. Secondly, we assess the role of sulfide oxidation, carbonation and simple hydrolysis as dominant chemical weathering processes in these systems. Finally, we estimate solute fluxes and the chemical denudation rates and compare these to data from other glacierised basins worldwide. The results from this study provide new insights into the seasonal geochemical dynamics occurring in the glacial and proglacial environments of a highly reactive glacierised basin. 


\section{Study area}

144 Werenskioldbreen $\left(77^{\circ} 05^{\prime} \mathrm{N}, 15^{\circ} 15^{\prime} \mathrm{E}\right)$ is located in Wedel-Jarlsberg Land, Southwest 145 Spitsbergen (Fig. 1). Its basin area covers $44.1 \mathrm{~km}^{2}$, of which $27.4 \mathrm{~km}^{2}$ are glacierised. The 146 glacier is $9.5 \mathrm{~km}$ in length and is a typical land-terminating, valley-type polythermal glacier of 147 this region of Svalbard (Hagen et al., 1993). The glacier elevation ranges from 60 to $650 \mathrm{~m}$ a.s.l (Hagen et al., 1993) and the equilibrium line altitude (ELA) of the glacier is situated at $450 \mathrm{~m}$ a.s.l (Grabiec et al., 2012), although in the period 2009-2011 the ELA was above the maximal altitude of glacier (Ignatiuk and Migała, 2013). The mean annual mass balance was $0.43 \mathrm{~m}$ water equivalents during the period 1912-2005 (Grabiec et al., 2012). The maximum glacier thickness is approximately $235 \pm 15 \mathrm{~m}$ (Ignatiuk and Migała, 2013), consisting of a 50$100 \mathrm{~m}$ thick surface layer of cold ice with temperate ice below (Pälli et al., 2003). At the 50 $\mathrm{m}$ thick snout, the glacier is frozen to the underlying bedrock and this cold-based zone extends to a distance of $0.7-1 \mathrm{~km}$ up-glacier (Pälli et al., 2003). a subglacial reservoir with bulk meltwater emerging from a few subglacial outflows at the front (Pulina et al., 1999a). Four moulin systems have been observed to survive for more than one ablation season: Lipertaven, Kvisla Cave and those below Eimfjellet and

Glasiologknausen; all other moulins are closed after a single ablation season due to ice deformation (Rehak et al., 1990). The drainage system of Werenskioldbreen is subject to interannual variability as observed by migration of the positions of subglacial outflows (Pälli et al., 2003). In the years 1983, 1986, 1988 and 1993, the main outflow was situated at the northern part of the glacier front (emerging at Kvisla) and minor outflows were situated in the central part (Krawczyk and Opołka-Gądek, 1994). This configuration changed in the years 1998, 2007 and 2008, where the main outflow shifted position to the central part of the glacier 
167 front (Pulina et al., 1999a; Kies et al., 2011; Szynkiewicz et al., 2013). For 2010-2012, the

main outflow was situated at the northern part of the glacier again, where the river Kvisla emanates (Piechota et al., 2012). Subglacial outflows with sub-artesian features (Black spring and Dusan outflows) have been observed tens of meters in front of the central part of the glacier terminus (Głowicki, 1982).

\section{Geology and mineralogy within the Werenskioldbreen basin}

Geologically, Werenskioldbreen is underlain by the Caledonian Hecla Hoek succession formed in the contact zone between three Proterozoic tectonic blocks (Czerny et al., 1993): 1) the Eimfjellet group, consisting of amphibolite, quartzite and chlorite schist is situated beneath its southern part, 2) the Deilegga group beneath the eastern part of the glacier, comprised mainly of phyllites with quartzite and silt intercalations, and calcareous and chlorite schists (Kieres and Piestrzynski, 1992), and 3) the Jens Erikfjellet formation including the Sofiebogen group in the north-western part of the basin, composed of greenschists, and muscovite-carbonate-quartz or carbonate-chlorite-quartz schists. The proglacial area belongs to the Sofiebogen and Eimfjellet groups, where mica-carbonate-quartz and grey calcite marbles dominate (Czerny et al., 1993). The Elveflya formation belongs to Sofiebogen group and consists of similar rocks (Czerny et al., 1993) and pyrite accompanied by pyrrhotite, galena, sphalerite, magnetite and haematite are the most common ore minerals. The carbonate minerals are present as siderite, ankerite or Fe-calcite, and occur in the Deilegga and Eimfjellet groups (Czerny et al., 1993).

The mineral compositions of the bedrock, proglacial sediments and suspended sediments are summarised in Table 1. Along a chronosequence from recently uncovered sediment in front of the glacier to sediment exposed $\sim 80$ years ago, exchangeable $\mathrm{Ca}$ decreases more than other exchangeable major ions $(\mathrm{Mg}, \mathrm{Na}, \mathrm{K})$. In addition, dolomite and 
amphibolite contents and the ratio of chlorite:mica decrease and formation of secondary minerals is unlikely (Kabala and Zapart, 2012). The suspended sediment consists of magnesium chlorite, feldspars, muscovite, quartz, calcite, and dolomite (Bukowska-Jania, 2007). Despite a low proportion of calcium carbonate in the bedrock, calcium carbonate comprises more than $7 \%$ of the proglacial sediment mineralogy, partly due to precipitation of calcite from water in subglacial tills (Bukowska-Jania, 2007).

\section{Methodology}

\subsection{Field methods}

Field investigations in the basin of Werenskioldbreen were carried out from May $12^{\text {th }}$ to September $25^{\text {th }}$ 2011. Discharge measurements at the hydrometric station (Fig. 1), and water sampling and meteorological measurements on the glacier surface were performed in Werenskioldbreen basin.

Variations in water level were measured at the hydrometric station at the bank of the Breelva river, which is incised into the bedrock at the Little Ice Age moraine, approximately $1.6 \mathrm{~km}$ from the glacier front (point 4, Fig. 1). Water level was measured at 10-minute logging intervals using a Mini-Diver probe and corrected for atmospheric pressure using a BaroDiver probe (both made by Schlumberger). At the beginning of the ablation season, when the riverbanks were covered by thick layers of snow, water velocity was determined by the salt dilution method (Rantz, 1982). When water level increased, water velocity was measured with a Seba F1 current meter.Total runoff for the ablation season was calculated based on a 1hour running average of water level and a rating curve. A lack of water level data for September $2^{\text {nd }}-8^{\text {th }}$ was due to technical problems with the Mini-Diver probe, and this period was supplemented with estimated discharge (Majchrowska and Cichała-Kamrowska, 2013; Majchrowska et al., 2015) obtained by using the Deterministic Modelling Hydrological 
217 System (DMHS; Vinogradov et al., 2011). For detailed information on discharge

218 measurements, including errors, we refer the reader to Majchrowska et al. (2015).

219 The majority of water samples were collected from the hydrometric station twice per 220 day at 6:00 and 18:00 UTC $(\mathrm{N}=183)$ from May $12^{\text {th }}$ to September $25^{\text {th }}$. In addition,

221 opportunistic sampling was conducted from the subglacial outflows: Kvisla main $(\mathrm{N}=28)$

222 from May $12^{\text {th }}$ to September $25^{\text {th }}$, Dusan $(\mathrm{N}=24)$ from August $30^{\text {th }}$ to September $25^{\text {th }}$, and

223 Black spring $(\mathrm{N}=22)$ from August $21^{\text {st }}$ to September $20^{\text {th }}$. Meltwater samples of supraglacial

224 streams on the glacier surface were collected whenever possible $(\mathrm{N}=7)$. Between August $21^{\text {st }}$

225 and September $25^{\text {th }}$ samples were collected from a precipitation gauge situated in the vicinity

226 of the hydrometric station $(\mathrm{N}=6)$ to supplement precipitation samples collected at the Polish

227 Polar Station (PPS, $\sim 16 \mathrm{~km}$ south of Werenskioldbreen) in Hornsund $(\mathrm{N}=31)$ from May $1^{\text {st }}$ to

228 September $30^{\text {th }}$. It was not possible to collect precipitation on Werenskioldbreen itself during

229 the entire ablation period, so the precipitation chemistry is taken from samples collected at the

230 PPS and analyses of precipitation chemistry are performed there throughout the entire year.

231 Only precipitation samples with a charge balance error (CBE, Eq. (1)) below 30\%, which are

232 considered to show data unaffected by post-depositional processes such as evaporation, are

233 reported in this article. We include precipitation samples from May $1^{\text {st }}$ to May $12^{\text {th }}$ as the

234 ablation rate was low during this period (Majchrowska and Małarzewski, 2011) and solutes

235 were assumed to accumulate within the snowpack.

236

237

$C B E=\frac{\left(\left|\sum X^{+}-\sum X^{-}\right|\right)}{\left(\sum X^{+}+\sum X^{-}\right)} * 100 \%$

238

239

240

Where $X$ - ion concentration in meq $\mathrm{L}^{-1}$ in sample, $\sum X^{-}$- sum of anions in meq $\mathrm{L}^{-1}$ in sample, $\sum X^{+}$- sum of cations in meq $\mathrm{L}^{-1}$ in sample. 
From July $17^{\text {th }}$ to September $25^{\text {th }}$, the $\mathrm{pH}$ of water samples was determined in situ

using a portable multi-parameter Hanna Instrument 9828, performed according to the USGS manual (Gibs et al., 2007). The accuracy and precision of the $\mathrm{pH}$ measurements were \pm 0.02 and 0.01 , respectively.

\subsection{Ablation rate}

The ablation rate was calculated by converting the energy available for melt into water equivalents. The daily energy at the glacier surface available for melt has been previously calculated using an energy balance model (Ignatiuk, 2012), factoring in the meteorological parameters air temperature, air humidity, radiation balance and wind speed from two automatic weather stations located on the surface of Werenskioldbreen. The ablation rate for the entire season was calculated by summing the daily melt. The model results were validated by observed melt rates obtained from a sonic ranging sensor SR-50, patterns of snow-line retreat, mass balance calculations and proglacial discharge. Observed ablation from the SR-50 and modelled ablation had a coefficient of determination of $\mathrm{R}^{2}=0.99$ (Ignatiuk, 2012).

\subsection{Laboratory methods}

All water samples were vacuum-filtered immediately after collection using a Millipore filtration system with $0.45 \mu \mathrm{m}$ pore size Whatman nylon filters. The samples were subsequently stored in pre-rinsed $250 \mathrm{ml}$ HDPE bottles in cold, dark conditions (at a temperature of $\sim 4^{\circ} \mathrm{C}$ ). The analyses of alkalinity and ion concentrations were performed within a few weeks after sampling at the hydrochemical laboratory at the PPS.

Filtered water samples were analysed for the concentrations of cations $\left(\mathrm{Ca}^{2+}, \mathrm{Mg}^{2+}\right.$, $\left.\mathrm{Na}^{+}, \mathrm{K}^{+}\right)$and anions $\left(\mathrm{SO}_{4}{ }^{2-}, \mathrm{Cl}^{-}\right)$by ion chromatography (IC) at the PPS. Acidified samples were analysed for cation concentrations using an ion chromatograph Metrohm Compact IC 
761 with a Metrosep C4-150/4.0 column with Tartaric acid/Dipicolinic acid eluent. The anions were determined using a Metrohm Compact IC 761 with a Metrosep C4-150/4.0 column and suppressor mode with a $\mathrm{Na}_{2} \mathrm{CO}_{3} / \mathrm{NaHCO}_{3}$ eluent. Detection limits of the ion chromatography analyses for $\mathrm{Ca}^{2+}, \mathrm{Mg}^{2+}, \mathrm{Na}^{+}, \mathrm{K}^{+}, \mathrm{SO}_{4}{ }^{2-}, \mathrm{Cl}^{-}$and $\mathrm{NO}_{3}{ }^{-}$were $0.5 \mu \mathrm{eq} \mathrm{L} \mathrm{L}^{-1}, 0.8$ $\mu$ eq $\mathrm{L}^{-1}, 0.4 \mu$ eq $\mathrm{L}^{-1}, 0.3 \mu$ eq $\mathrm{L}^{-1}, 0.2 \mu$ eq $\mathrm{L}^{-1}, 0.3 \mu$ eq $\mathrm{L}^{-1}$ and $0.2 \mu$ eq $\mathrm{L}^{-1}$, respectively. Most samples had $\mathrm{NO}_{3}{ }^{-}$concentrations below the detection limit and therefore this element was not included in the $\mathrm{CBE}$ calculations. The precision level of all analyses was $1 \%$. Two reference samples (Analytical Reference Material Rain-97 and Reference Material No 409 (BCR-409)) were used to determine accuracy, which was usually below $10 \%$ for both reference samples. Accuracy was higher than $10 \%$ for $\mathrm{Na}^{+}(12 \%), \mathrm{K}^{+}(18 \%)$ and $\mathrm{Cl}^{-}(22 \%)$ for analytical reference material Rain-97 and $\mathrm{Mg}^{2+}$ (12\%) for reference material No. 409 (BCR-409). Alkalinity (predominantly $\mathrm{HCO}_{3}^{-}$) was determined by automatic titration using a Metrohm 702 SM Titrino and $\mathrm{pH}$ was measured simultaneously using a glass $\mathrm{pH}$ electrode Unitrode. The detection limit and precision of the alkalinity measurements were $10 \mu \mathrm{eq} \mathrm{L}^{-1}$. Samples for Si measurements were acidified with nitric acid and transported at low temperature to the Hydrogeological Laboratory at the University of Science and Technology in Krakow at $\sim 4^{\circ} \mathrm{C}$ and analysed with a Perkin Elmer ICP-OES Plasm 40 spectrometer. The detection limit was $3.32 \mu \mathrm{eq} \mathrm{L}^{-1}$.

CBE calculations were applied as a control of the chemical analysis quality and were calculated according to Eq. 1. The ranges of CBEs for all sites are shown in Table 2.

As the study site is adjacent to the sea, correction of surface water chemistry for marine aerosols is necessary (corrected concentrations are marked by an asterisk). This was based on the principle of constant ratios between major ion concentrations and $\mathrm{Cl}^{-}$in oceanic water, which are as follows: $\mathrm{SO}_{4}{ }^{2-} / \mathrm{Cl}^{-}=0.103, \mathrm{Na}^{+} / \mathrm{Cl}^{-}=0.86, \mathrm{~K}^{+} / \mathrm{Cl}^{-}=0.019, \mathrm{Ca}^{2+} / \mathrm{Cl}^{-}=$ $0.038, \mathrm{Mg}^{2+} / \mathrm{Cl}^{-}=0.195$ (Holland, 1978). As Cl-bearing minerals are absent in the rocks of 
292 Werenskioldbreen, $\mathrm{Cl}^{-}$is considered to be a conservative ion derived only from atmospheric 293 input by dry or wet deposition of marine aerosols. Correction of sea-salts was calculated 294 based on Eq. 2:

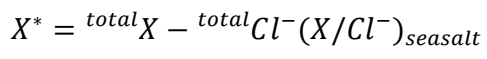

The sulfate mass fraction (SMF) was calculated using Eq. 3:

$$
\mathrm{SMF}=* \mathrm{SO}_{4}{ }^{2-} /\left(* \mathrm{SO}_{4}{ }^{2-}+\mathrm{HCO}_{3}{ }^{-}\right)
$$

* $\mathrm{SO}_{4}{ }^{2-}$ - the concentration of sulfate, corrected for atmospheric input (in $\mu \mathrm{eq} \mathrm{L}^{-1}$ ), $\mathrm{HCO}_{3}{ }^{-}-$the concentration of bicarbonates (in $\mu \mathrm{eq} \mathrm{L}^{-1}$ ).

\subsection{Solute flux, precipitation load and chemical denudation computations}

Solute fluxes were calculated by multiplication of discharge-weighted mean ion concentration and mean daily discharge and standardised for catchment area size. The chemical denudation rate was calculated by using both mean concentration and discharge-weighted mean concentration to estimate the mean ion concentrations. The chemical weathering intensity (CWI) was calculated by dividing the cation denudation rate $\left(m e q \mathrm{~m}^{-2} \mathrm{a}^{-1}\right)$ by specific annual runoff $\left(\mathrm{m} \mathrm{a}^{-1}\right)$ according to Krawczyk et al. (2003). Solute load from precipitation was calculated by using the sum of precipitation from the PPS and mean ions concentration and then by using a gradient of $19 \%$ per $100 \mathrm{~m}$ of altitude increase as suggested for glacierised basins in Svalbard by Nowak and Hodson (2013).

\section{Results}




\subsection{Chemical characteristics of precipitation and supraglacial waters}

To better understand the chemistry of surface water within the Werenskioldbreen basin, we first examined the precipitation chemistry from Werenskioldbreen and PPS (situated $\sim 16 \mathrm{~km}$ to the south of Werenskioldbreen at Hornsund Fjord) to gain information on the local atmospheric deposition of solutes (Table 3). Due to lack of data coverage for Werenskioldbreen, we used data from the PPS because this dataset covers the entire ablation season. During the study period (May $1^{\text {st }}-$ September $30^{\text {th }} 2011$ ), the total precipitation amounted to $250.3 \mathrm{~mm}$ at the PPS. Snowfall was only registered twice, on May $4^{\text {th }}$ and May $26^{\text {th }}$.

Sodium ions in precipitation were derived primarily from seawater (Eq. (2)), whilst $\mathrm{K}^{+}, \mathrm{Ca}^{2+}, \mathrm{Mg}^{2+}$ and $\mathrm{SO}_{4}{ }^{2-}$ originated mainly from dust transport in the atmosphere (Table 3 ). Non-sea salts $\mathrm{SO}_{4}{ }^{2-}$ and $\mathrm{Mg}^{2+}$ may be sourced from the dissolution of aged (reacted) sea salt that underwent reaction with the nitrogen and sulfur oxides during transport in the atmosphere, whereas $\mathrm{Ca}^{2+}, \mathrm{Mg}^{2+}$ and $\mathrm{K}^{+}$of non-sea salt origin may come from the mineral dust particles generated by wind erosion and transport of rock/sediment particles (Geng et al. 2010). The precipitation chemistry in the Werenskioldbreen basin was generally in the same range as in Hornsund (Tables 3), but some deviations between mean ionic concentrations occurred. In the Werenskioldbreen basin, $\mathrm{Mg}^{2+}, \mathrm{Cl}^{-}, \mathrm{Na}^{+}$and $\mathrm{K}^{+}$concentrations were $2-3$ times lower than at Hornsund, whereas $\mathrm{SO}_{4}{ }^{2-}$ was similar in concentration and $\mathrm{Ca}^{2+}$ was 3 times higher. The chemical analyses of snowpack samples from two snow pit excavations on Werenskioldbreen showed that ionic ratios were very similar to the marine ratios: $\mathrm{SO}_{4}{ }^{2-} / \mathrm{Cl}^{-}=$ $0.123, \mathrm{Na}^{+} / \mathrm{Cl}^{-}=0.85, \mathrm{~K}^{+} / \mathrm{Cl}^{-}=0.016, \mathrm{Ca}^{2+} / \mathrm{Cl}^{-}=0.051, \mathrm{Mg}^{2+} / \mathrm{Cl}^{-}=0.18$. Precipitation had higher concentrations of most ions, excluding $\mathrm{Ca}^{2+}$, than supraglacial streams (Table 3, 4). The enhanced $\mathrm{Ca}^{2+}$ concentration in supraglacial streams may originate from dissolution of carbonate dust deposited on the glacier surface. 


\subsection{Water chemistry at subglacial conditions}

345 All ion concentrations increased from the supraglacial stream to subglacial outflows (Kvisla,

346 Black spring, Dusan) by more than one order of magnitude. Magnesium and $\mathrm{SO}_{4}{ }^{2-}$ showed the

347 greatest increases from supraglacial streams to the Kvisla subglacial outflow (from 5 to 220

348 ueq $\mathrm{L}^{-1}$ and from 6 to $\sim 240$ ueq $\mathrm{L}^{-1}$, respectively; Table 4), whereas $\mathrm{Cl}^{-}$exhibited the lowest

349 increase. Mean concentrations of all ions (excluding $\mathrm{K}^{+}$) in Kvisla were higher than in the

350 sub-artesian subglacial outflows (Black spring and Dusan, Table 4), but minimum

351 concentrations of $\mathrm{Na}^{+}$and $\mathrm{K}^{+}$were lower. The ratios of $\mathrm{HCO}_{3}{ }^{-}: \mathrm{SO}_{4}{ }^{2-}$ and $\mathrm{Ca}^{2+}$ concentrations

352 were also higher in Kvisla than in other subglacial outflows. However, the dissolved silica

353 concentration $\left(\mathrm{SiO}_{2}\right)$ was higher by a factor of 1.5 in both sub-artesian outflows than in

354 Kvisla. Water $\mathrm{pH}$ was similar in all subglacial outflows ( $\mathrm{pH}$ 8.8-9.1) and substantially higher

355 than in supraglacial streams $(\mathrm{pH} \sim 5.5)$.

\subsection{Temporal trends of water chemistry at the hydrometric station}

At the hydrometric station, all ion concentrations increased proportionally from subglacial outflows. From Kvisla main to the hydrometric station, the ion concentrations increased for $\mathrm{K}^{+}$by a factor of 1.5 , and for $\mathrm{SO}_{4}{ }^{2-}$ and $\mathrm{Mg}^{2+}$ by a factor of 1.3 . At the hydrometric station, $\mathrm{SiO}_{2}$ was lower than at the sub-artesian subglacial outflows (Dusan, Black spring). and Fig. 2. We divided the ablation season into three periods: early ablation (12 May - 18 June 2011), peak flow (19 June - 10 September 2011) and late ablation (11 September - 25 
and a decrease in ion concentrations. At the beginning of September, the transition from the peak flow season to the late ablation season was characterised by an increase in crustallyderived ions.

\section{Early ablation season}

During the early ablation season, a marked drop in the concentration of all ions occurred at the hydrometric station. Sodium and $\mathrm{Cl}^{-}$decreased from $900 \mu \mathrm{eq} \mathrm{L}^{-1}$ to $300 \mu \mathrm{eq} \mathrm{L}^{-1}$, whereas $\mathrm{SO}_{4}{ }^{2-}$ and $\mathrm{Mg}^{2+}$ fell from $700 \mu \mathrm{eq} \mathrm{L}^{-1}$ to $300 \mu \mathrm{eq} \mathrm{L}{ }^{-1}$ (Fig. 2). By the end of May, the concentrations of $\mathrm{Na}^{+}, \mathrm{Cl}^{-}$and $\mathrm{Mg}^{2+}$ had decreased substantially as a result of a rain event. The concentrations of $\mathrm{Na}^{+}$and $\mathrm{Cl}^{-}$responded quickly to the discharge increase, while the concentrations of $\mathrm{Ca}^{2+}\left(\sim 1100 \mu \mathrm{eq} \mathrm{L} \mathrm{L}^{-1}\right)$ and $\mathrm{HCO}_{3^{-}}\left(\sim 900 \mu \mathrm{eq} \mathrm{L}^{-1}\right)$ declined to 600 and $700 \mu \mathrm{eq}$ $\mathrm{L}^{-1}$, respectively. $\mathrm{Ca}^{2+}$ made the largest contribution to the cation total, usually exceeding $40 \%$, while both $\mathrm{Mg}^{2+}$ and the sum of $\mathrm{Na}^{+}$and $\mathrm{K}^{+}$contributed over $20 \%$ each (Fig. 3). In terms of the anion composition, $\mathrm{HCO}_{3}{ }^{-}$showed a concentration above $40 \%$ of the total, whereas the other anions contributed approximately $20 \%$ (Fig. 3). In contrast to these decreases, the concentrations of $\mathrm{SO}_{4}{ }^{2-}, \mathrm{HCO}_{3}{ }^{-}, \mathrm{Na}^{+}$and $\mathrm{Cl}^{-}$were at a relatively constant level during the early ablation season from May $18^{\text {th }}$ to May $28^{\text {th }}$ ranging from 600 to $800 \mu$ eq $\mathrm{L}^{-1}$ (Fig. 2).

\section{Peak flow season}

At the beginning of the peak flow season, discharge exceeded $5 \mathrm{~m}^{3} \mathrm{~s}^{-1}$ corresponding to an increase in the rate of ablation (Fig. 2). During the initial period of moderate ablation between June $18^{\text {th }}$ and July $7^{\text {th }}$, the ion concentrations remained similar to their values at the end of the early ablation season. Peaks in ion concentrations were noted for $\mathrm{Ca}^{2+}$ and $\mathrm{HCO}_{3}{ }^{-}$from June $23^{\text {rd }}$ to $26^{\text {th }}$ (Fig. 2); whereas the concentration maximums of $\mathrm{Na}^{+}$and $\mathrm{Cl}^{-}$were observed from 
June $26^{\text {th }}$ to $30^{\text {th }}$ (Figs. 2, 3) and $\mathrm{Na}^{+}$and $\mathrm{Cl}^{-}$exhibited elevated concentration levels from June $19^{\text {th }}$ to July $7^{\text {th }}$ (Fig. 4). These changes indicate a significant leaching of ions from snowmelt. The strongest inverse correlation between an ion concentration and discharge was observed for $\mathrm{Na}^{+}(\mathrm{r}<-0.70)$. Increase in the ablation rate in the later part of the peak flow season caused a peak in discharge that exceeded $15 \mathrm{~m}^{3} \mathrm{~s}^{-1}$. Ion concentrations decreased throughout this period due to dilution, reaching a minimum in mid-July. The concentrations of $\mathrm{Na}^{+}, \mathrm{Cl}^{-}$, $\mathrm{Mg}^{2+}$ and $\mathrm{SO}_{4}{ }^{2-}$ dropped to below $200 \mu \mathrm{eq} \mathrm{L}^{-1}$, whereas $\mathrm{Ca}^{2+}$ and $\mathrm{HCO}_{3}{ }^{-}$had concentrations ranging from $400 \mu \mathrm{eq} \mathrm{L}^{-1}$ to $700 \mu \mathrm{eq} \mathrm{L}^{-1}$. The reduction in the concentrations of $\mathrm{Ca}^{2+}$ and $\mathrm{Mg}^{2+}$ coincided with the increase in discharge (Fig. 5). From August $26^{\text {th }}$ to September $11^{\text {th }}$ the concentration ratio of $\mathrm{SO}_{4}{ }^{2-}$ to $\mathrm{Ca}^{2+}$ and $\mathrm{HCO}_{3}{ }^{-}$increased. The water chemistry of the peak flow and late ablation seasons at the hydrometric station was similar to that of Kvisla, whereas the other subglacial outflows (Black spring, Dusan) are clustered in a separate group in the Piper diagram due to the total concentrations of $\mathrm{Na}^{+}$and $\mathrm{K}^{+}$exceeding $20 \%$ (Fig. 3).

\section{Late ablation season}

During the late ablation season, the ablation rate decreased by comparison to the preceding peak flow season and the concentrations of most ions increased (with the exception of the primarily snowpack-derived ions $\mathrm{Na}^{+}$and $\mathrm{Cl}^{-}$). The increase in concentrations of $\mathrm{SO}_{4}{ }^{2-}$ and $\mathrm{Mg}^{2+}$ was most pronounced (from $\sim 200 \mu \mathrm{eq} \mathrm{L}^{-1}$ to $500-600 \mu \mathrm{eq} \mathrm{L}^{-1}$ ). The SMF was $\sim 0.4$, which was higher than that of the peak flow season, while the daily discharge ranged from 5 to $16 \mathrm{~m}^{3} \mathrm{~s}^{-1}$ (Fig. 5). The contribution of $\mathrm{SO}_{4}{ }^{2-}$ to the total anion concentration reached $40 \%$, exceeding the proportion observed in the early ablation season (Fig. 3). Both SMF and $\mathrm{Mg}^{2+}$ were similar to the beginning of early ablation season (Figs. 2, 5), and the concentrations of $\mathrm{Na}^{+}$and $\mathrm{Cl}^{-}$remained below $100 \mu \mathrm{eq} \mathrm{L}^{-1}$, resembling those of the peak flow season. 


\subsection{Seasonal solute fluxes and chemical weathering rates}

419 The solute flux rates fluctuated between the seasonal periods of the ablation season (Table 6).

420

421

422

423

424

425

426

427

428

429

430

431

432

433

434

435

436

437

438

439

440

441
Maximum solute flux rates were observed during the peak flow and late ablation seasons, exceeding $1000 \mathrm{~kg}_{\text {day }}{ }^{-1} \mathrm{~km}^{-2}$, whereas the observed solute flux rates during the early

ablation season were three times lower. Mean daily fluxes of dissolved constituents during the entire ablation season were arranged in descending order of magnitude (in $\mathrm{kg} \mathrm{day}^{-1} \mathrm{~km}^{-2}$ ):

$\mathrm{HCO}_{3}{ }^{-}(565.6)>* \mathrm{Ca}^{2+}(201.7)>* \mathrm{SO}_{4}{ }^{2-}(193.9)>>* \mathrm{Mg}^{2+}(36.8)>>\mathrm{SiO}_{2}(8.5)>* \mathrm{~K}^{+}(7.2)>$ $* \mathrm{Na}^{+}(4.0)$. The fluxes of $* \mathrm{SO}_{4}{ }^{2-}, * \mathrm{Mg}^{2+}$ and $\mathrm{SiO}_{2}$ reflected a clear and gradual increase from early to late ablation season by a factor of two or more. The proportion of non-sea salt $\mathrm{SO}_{4}{ }^{2-}$ flux decreased throughout the ablation season from $8 \%$ to $2 \%$. The most prominent seasonal increase in flux was noted for $* \mathrm{Na}^{+}$exceeding one order of magnitude, whereas the $\mathrm{Cl}^{-}$flux showed a nearly two-fold decline from early to late ablation season.

The solute yields at the hydrometric station and precipitation are shown in Table 7.

The runoff, ablation and precipitation totals for the entire ablation season were estimated to be $80.6 \times 10^{6} \mathrm{~m}^{3}, 49.8 \times 10^{6} \mathrm{~m}^{3}$ and $14.1 \times 10^{6} \mathrm{~m}^{3}$, respectively. The runoff and precipitation totals in the peak flow and late ablation seasons were $9 \%$ and $17 \%$ lower than the respective totals for the entire ablation season. The cationic denudation rate (CDR) was $1601 \mathrm{meq} \mathrm{m}^{-2} \mathrm{yr}^{-1}$ based on the discharge-weighted ion concentration, whereas if the mean concentration is used for calculating the CDR, it was estimated to $1762 \mathrm{meq} \mathrm{m}^{-2} \mathrm{yr}^{-1}$. The solute yields from the precipitation corrected for marine aerosols reached only $8 \mathrm{meq} \mathrm{m}^{-2} \mathrm{yr}^{-1}$. The chemical weathering intensity (CWI) indices, calculated according to Krawczyk et al. (2003), were less than $1000 \mathrm{meq} \mathrm{m}^{-3} \mathrm{yr}^{-1}$. We can assume that the combined denudation rate of the proglacial and subglacial areas measured at the hydrometric station was equal to sea-salt corrected solute yields because the proportion of solute yield delivered by rain was negligible (Table 7). 
442 Solutes derived from snowmelt were calculated from the marine ratio and were excluded from total solute yields by sea-salt correction of water chemistry.

\section{Discussion}

Chemical weathering in glacierised catchments depends on reactions providing $\mathrm{H}^{+}$ions that dissolve mineral/rock surfaces, such as sulfide oxidation, carbonation, organic carbon oxidation and simple hydrolysis. Dissolution of silicate or carbonate minerals is coupled to these reactions (e.g., sulfide oxidation coupled to carbonate/feldspar dissolution, carbonation of carbonate/feldspar surface Eqs (4-7)). These coupled reactions affect the water chemistry of a solution by enriching it with ions resulting in altered ion ratios and different slopes and intercepts in linear regression equations. These reactions are particularly important for Werenskioldbreen as evidenced by the linear regression coefficients and scatterplots of ions (Table 8; Fig. 6). Sulfide oxidation coupled to carbonate dissolution (SOCD) has slope coefficients of 2.0 and 1.0 for ion associations with $\left[{ }^{*} \mathrm{Ca}^{2+}+* \mathrm{Mg}^{2+}\right.$ vs. $\left.{ }^{*} \mathrm{SO}_{4}{ }^{2-}\right]$ and $\left[\mathrm{HCO}_{3}{ }^{-}\right.$vs. * $\left.\mathrm{SO}_{4}{ }^{2-}\right]$, respectively (Eq.( 4); Tranter et al., 2002; Wadham et al., 2010a). Carbonation of 457 carbonates is characterised by a slope coefficient of 1.0 for the ion association $\left[{ }^{*} \mathrm{Ca}^{2+}+* \mathrm{Mg}^{2+}\right.$ vs. $\mathrm{HCO}_{3}{ }^{-}$] (Eq.( 6)). Dissolution of $\mathrm{Ca}$ and $\mathrm{Mg}$ efflorescent salts favours an ion association $\left[* \mathrm{Ca}^{2+}+* \mathrm{Mg}^{2+}\right.$ vs. $\left.* \mathrm{SO}_{4}{ }^{2-}\right]$ slope close to 1.0 (Eq. (8), Szynkiewicz et al., 2013). Sulfide oxidation coupled to $\mathrm{Na}, \mathrm{K}$ silicate dissolution causes increase in $\mathrm{SO}_{4}{ }^{2-}$ concentrations leading to increase in the slope of the ion association $\left[{ }^{*} \mathrm{SO}_{4}{ }^{2-}\right.$ vs. $\left.\mathrm{HCO}_{3}{ }^{-}\right]$and decrease in the slope of 462 the ion association $\left[* \mathrm{Ca}^{2+}+* \mathrm{Mg}^{2+}\right.$ vs. $\left.{ }^{*} \mathrm{SO}_{4}{ }^{2-}\right]$ (Eq. (5)). Also, Tranter et al. (2002) suggested that intercepts of $220 \mu \mathrm{eq} \mathrm{L}^{-1}$ in ions associations $\left[* \mathrm{Ca}^{2+}+* \mathrm{Mg}^{2+}\right.$ vs. $\left.* \mathrm{SO}_{4}{ }^{2-}\right]$ and $\left[\mathrm{HCO}_{3}{ }^{-}\right.$vs. * $\left.\mathrm{SO}_{4}{ }^{2-}\right]$ indicate simple hydrolysis of carbonate at the initial stage of water contact with subglacial sediments (Eq.(9)), whereas higher intercepts indicate additional chemical reactions forming $\mathrm{H}^{+}$ions such as organic carbon oxidation (Eq.( 10)). In case of simple 
467 hydrolysis of silicate, concentrations of cations and $\mathrm{OH}^{-}$increase (pH increases) but intercepts

468 remain unchanged (Eq. (11)).

469

470

Equation 4. Sulfide oxidation coupled to carbonate dissolution (SOCD)

471

$4 \mathrm{FeS}_{2}(s)+16 \mathrm{Ca}_{1-x}\left(\mathrm{Mg}_{x}\right) \mathrm{CO}_{3}(s)+15 \mathrm{O}_{2}(a q)+14 \mathrm{H}_{2} \mathrm{O}(\mathrm{l}) \rightleftharpoons 16(1-x) \mathrm{Ca}^{2+}(a q)+16 x \mathrm{Mg}^{2+}(a q)+$

472

$16 \mathrm{HCO}_{3}^{-}(\mathrm{aq})+8 \mathrm{SO}_{4}^{2-}(\mathrm{aq})+4 \mathrm{Fe}(\mathrm{OH})_{3}(\mathrm{~s})(4)$

473

474

Equation 5. Sulfide oxidation coupled to silicate weathering ( $\mathrm{SOSW}$ )

475

$4 \mathrm{FeS}_{2}(s)+16 \mathrm{Na}_{1-x} \mathrm{~K}_{x} \mathrm{AlSi}_{3} \mathrm{O}_{8}(s)(s)+15 \mathrm{O}_{2}(a q)+86 \mathrm{H}_{2} \mathrm{O}(\mathrm{l}) \rightleftharpoons 16(1-x) \mathrm{Na}^{+}(a q)+16 x \mathrm{~K}^{+}(a q)+$

476

$8 \mathrm{SO}_{4}^{2-}(\mathrm{aq})+4 \mathrm{Al}_{4} \mathrm{Si}_{4} \mathrm{O}_{10}(\mathrm{OH})_{8}(\mathrm{~s})+32 \mathrm{H}_{4} \mathrm{SiO}_{4}(\mathrm{aq})+4 \mathrm{Fe}(\mathrm{OH})_{3}(\mathrm{~s})(5)$

477

478

Equation 6. Carbonation of carbonate $\mathrm{Ca}_{1-x}\left(\mathrm{Mg}_{x}\right) \mathrm{CO}_{3}(s)+\mathrm{CO}_{2}(a q)+\mathrm{H}_{2} \mathrm{O}(\mathrm{l}) \rightleftharpoons(1-x) \mathrm{Ca}^{2+}(a q)+$

479

$x \mathrm{Mg}^{2+}(a q)+2 \mathrm{HCO}_{3}^{-}(a q)(6)$

480

481

Equation 7. Carbonation of feldspar surfaces (albite/microcline - orthoclase)

482

$2(\mathrm{Na} \mathrm{K}) \mathrm{AlSi}_{2} \mathrm{O}_{8}(\mathrm{~s})+2 \mathrm{CO}_{2}(a q)+9 \mathrm{H}_{2} \mathrm{O}(a q) \rightleftharpoons 2 \mathrm{Na}^{+}, \mathrm{K}^{+}(a q)+2 \mathrm{HCO}_{3}^{-}(a q)+\mathrm{Al}_{2} \mathrm{Si}_{2} \mathrm{O}_{5}(s)+$

483

$4 \mathrm{H}_{4} \mathrm{SiO}_{4}(\mathrm{aq})$

484

485

486

Equation 8. Dissolution of gypsum (an example of efflorescent salts)

$\mathrm{CaSO}_{4} \cdot 2 \mathrm{H}_{2} \mathrm{O}(\mathrm{s}) \rightleftharpoons \mathrm{Ca}^{2+}(a q)+\mathrm{SO}_{4}^{2-}(a q)+2 \mathrm{H}_{2} \mathrm{O}(\mathrm{l})$

487

488

489

Equation 9. Simple hydrolysis of carbonate

$\mathrm{Ca}_{1-x}\left(\mathrm{Mg}_{x}\right) \mathrm{CO}_{3}(s)+\mathrm{H}_{2} \mathrm{O}(\mathrm{l}) \rightleftharpoons(1-x) \mathrm{Ca}^{2+}(a q)+x \mathrm{Mg}^{2+}(a q)+\mathrm{HCO}_{3}^{-}(a q)+\mathrm{OH}^{-}(a q)$

490

491

Equation 10. Oxidation of organic carbon

492

$\mathrm{C}_{\text {org }}(\mathrm{s})+\mathrm{O}_{2}(a q)+\mathrm{H}_{2} \mathrm{O}(l) \rightleftharpoons \mathrm{CO}_{2}(a q)+\mathrm{H}_{2} \mathrm{O}(l) \rightleftharpoons \mathrm{H}^{+}(a q)+\mathrm{HCO}_{3}^{-}(a q)$

493

494

Equation 11. Simple hydrolysis of feldspar

495

$\mathrm{KAlSi}_{3} \mathrm{O}_{8}(s)+\mathrm{H}_{2} \mathrm{O}(\mathrm{l}) \rightleftharpoons \mathrm{HAlSi}_{3} \mathrm{O}_{8}+\mathrm{K}^{+}(a q)+\mathrm{OH}^{-}(a q)$

496

497

A SMF (calculated from Eq. (3)) equal to 0.5 corresponds to predominating SOCD

498

(Eq. (4)). Carbonation of carbonates decreases SMF below 0.5 due to excess of $\mathrm{HCO}_{3}{ }^{-}$(Eq.

499

(6)), whereas SMF increases above 0.5 for SOSW due to $\mathrm{SO}_{4}{ }^{2-}$ excess (Eq. (5)), carbonate

500 precipitation and $\mathrm{Ca}$ andMg efflorescent salt dissolution (Eq. (8)) (Cooper et al., 2002;

501 Tranter et al., 2002).

502 


\subsection{Evolution of meltwater chemistry during the ablation season (hydrometric station)}

Meltwater in the ablation season of 2011 in Werenskioldbreen basin exhibited three periods of distinct characteristics: early ablation, peak flow and late ablation. During May, low ablation rates associated with high ion concentrations indicated leaching of ions from the snowpack in combination with release of solute-rich meltwater stored in the subglacial drainage system throughout the winter season (Fig. 2). The release of subglacial water by breaking domeshaped naled ice formed in front of Werenskioldbreen increased ion concentrations (Krawczyk and Wach, 1993; Pulina et al., 1999b; Yde et al., 2012) during this period as well, and concentrations are apparently further augmented by brine exclusion during freezing in the early ablation season (Pulina, 1984). Meltwater during the late ablation season could endure the winter in the form of ice and liquid water stored in the glacier drainage system. In the following early ablation season this meltwater may contribute to high concentrations of crustally derived ions $\left(* \mathrm{Ca}^{2+}, * \mathrm{Mg}^{2+}, * \mathrm{Na}^{+}, * \mathrm{~K}^{+}, * \mathrm{SO}_{4}{ }^{2-}\right)$ and low concentration of dissolved sea-salts $\left(\mathrm{Na}^{+}, \mathrm{Cl}^{-}\right)$. However, we observed excess $\mathrm{Na}^{+}$and $\mathrm{Cl}^{-}$in the early ablation season and at the beginning of the peak flow season, indicating that there is leaching of sea salts that accumulated in the snowpack throughout the winter.

On May $28^{\text {th }}$, a short period of rain and positive air temperature caused a hydrochemical regime shift in runoff from the basin. The large volume of water created by this event diluted the concentrations of all ions at the hydrometric station. A similar drop in ion concentrations at the transition from the early ablation season to the peak flow season was observed at the subglacial outflows of Werenskioldbreen in 1986 (Krawczyk, 1992).

However, the decrease we observed was disproportionally distributed between particular ion groups. After a short decrease, the concentrations of $\mathrm{Ca}^{2+}$ and $\mathrm{HCO}_{3}{ }^{-}$increased to above 700 $\mu$ eq $\mathrm{L}^{-1}$ after June $7^{\text {th }}$, possibly due to the dissolution of pure calcite. Furthermore, in the early ablation season high input of ablation waters and the absence of an efficient subglacial 
drainage network probably enhance calcite dissolution in the proglacial area. Recrystallisation of calcite has also been shown to increase the content of $\mathrm{CaCO}_{3}$ in the proglacial sediments of Werenskioldbreen by $47 \%$ (Bukowska-Jania, 2007), and aerated waters reaching the subglacial system and proglacial groundwater could promote the processes of carbonation of $\mathrm{CaCO}_{3}$ via atmospheric $\mathrm{CO}_{2}$ (Tranter et al., 2002). However, slope coefficients of ion associations $\left[{ }^{*} \mathrm{Ca}^{2+}+* \mathrm{Mg}^{2+}\right.$ vs. $\left.\mathrm{HCO}_{3}{ }^{-}\right]$and $\left[{ }^{*} \mathrm{Ca}^{2+}+* \mathrm{Mg}^{2+}\right.$ vs. $\left.{ }^{*} \mathrm{SO}_{4}{ }^{2-}\right]$ were $\sim 2.1$ and $\sim 1.7$, respectively, and the correlation coefficient for these ion associations exceeded 0.9 , indicating that SOCD is more likely to occur than carbonation of carbonates (Table 8, Fig. 6).. These results reveal a dominance of SOCD during the early ablation season. This is supported by the fact that both snowmelt-saturated groundwater in the proglacial zone and aerated water in the subglacial drainage system contribute to enhance sulfide oxidation in the catchment. Also, pronounced sulfide oxidation results from subglacial meltwater storage during the accumulation season (Wadham et al. 2001). Furthermore. in the early ablation season the release of $\mathrm{Ca}^{2+}$ is related to SOCD (preferentially calcite) dissolution and the release of old waters from storage suggesting that dissolution of atmospheric $\mathrm{CO}_{2}$ appears to play a minor role in chemical weathering processes.

The results also indicate that SOCD only partly explains chemical weathering during the early ablation season because slope coefficients differ from the theoretical stoichiometric coefficients (Eq. (4)). Excess $* \mathrm{SO}_{4}{ }^{2-}$ resulted in a slope coefficient of $\sim 0.6$ in ion association $\left[\mathrm{HCO}_{3}{ }^{-}\right.$vs. $\left.{ }^{*} \mathrm{SO}_{4}{ }^{2-}\right]$ and a slope coefficient of $\left[{ }^{*} \mathrm{Ca}^{2+}+* \mathrm{Mg}^{2+}\right.$ vs. $\left.{ }^{*} \mathrm{SO}_{4}{ }^{2-}\right]$ lower than 2.0 , both of which suggest an additional source of sulfate (i.e. Ca-Mg efflorescent salt, dissolution of sulfur bearing minerals accumulated in the snow, and SOCD). The slope and correlation coefficient of the ion association $\left[\mathrm{HCO}_{3}{ }^{-}\right.$vs. $\left.* \mathrm{SO}_{4}{ }^{2-}\right]$ were lowest during the early ablation season, indicating that multiple reactions dominated in the proglacial zone. SOSW could also result in an excess of $\mathrm{SO}_{4}{ }^{2-}$ and explain the decrease of these slopes because total fluxes of 
553 ions derived from the dissolution of silicates $\left(* \mathrm{Na}^{+}, * \mathrm{~K}^{+}\right)$were lower by a factor of ten than

554 carbonate ions $\left(\mathrm{Ca}^{2+}\right)$. However, increase of silicate-derived ions and sulfate fluxes suggest

555 that SOSW increased in importance throughout the ablation season.

556 The maximum discharge in July was caused by the rapid melting of the snowpack in

557 the basin following another air temperature increase and rain event $\left(9^{\text {th }} \mathrm{July}\right)$. Preceding this

558 rapid melting of the snowpack, an period of high $\mathrm{Na}^{+}$and $\mathrm{Cl}^{-}$concentrations at the end of

559 June occurred along with increased snowmelt and coinciding with the retreat of the snowline

560 to $200 \mathrm{~m}$ a.s.l. (Ignatiuk, 2012). The high concentrations of $\mathrm{HCO}_{3}{ }^{-}$and $\mathrm{Ca}^{2+}$ preceding this

561 period signalled the late stage of naled ice degradation and the release of stored water from

562 the winter reservoir (Fig. 2). The subsequent pronounced increase in the concentrations of $\mathrm{Na}^{+}$

563 and $\mathrm{Cl}^{-}$ions indicate the melting of naled ice and snow. Concentrations of other ions related to

564 dissolution of rocks $\left(\mathrm{Ca}^{2+}\right.$ and $\left.\mathrm{Mg}^{2+}\right)$ appear to remain stable, suggesting that the

565 hydrochemical switching is in agreement with the hydrological change in the glacier basin. A

566 shorter response time of the discharge for air temperatures and precipitation events during

567 high ablation also suggests that an ongoing development of an efficient subglacial drainage

568 system is occurring. At the same time, the difference between the sum of $\mathrm{Ca}^{2+}$ and $\mathrm{HCO}_{3}{ }^{-}$and

569 the sum of $\mathrm{SO}_{4}{ }^{2-}$ and $\mathrm{Mg}^{2+}$ increased along with rising discharge (Fig. 2, Table 5). This may

570 be attributed to suspended sediments which are present in high concentrations at this time and

571 are highly reactive due to their high surface area (Anderson, 2005; Anderson, 2006).

572 Laboratory experiments on freshly comminuted glacial flour (Brown et al., 1994; Brown et

573 al., 1996) together with field data (Hallet et al., 1996; Anderson, 2006; Fairchild et al., 1999)

574 suggest an enrichment of $\mathrm{Ca}^{2+}$ and $\mathrm{HCO}_{3}{ }^{-}$by carbonation of suspended sediments in open

575 channels in the proglacial area or in subglacial conduits. The prominent decrease in the slope

576 of the ion association $\left[{ }^{*} \mathrm{Ca}^{2+}+* \mathrm{Mg}^{2+}\right.$ vs. $\left.\mathrm{HCO}_{3}{ }^{-}\right]$from early ablation season to late ablation

577 season suggests carbonation. However, the slope of the ion association $\left[\mathrm{HCO}_{3}{ }^{-}{ }^{-}\right.$s. $\left.{ }^{*} \mathrm{SO}_{4}{ }^{2-}\right]$ is 
close to 1.0 revealing a predominance of sulfide oxidation coupled to carbonate dissolution (SOCD), which operates under subglacial conditions and also in the proglacial zone.

Nevertheless, the low correlation coefficient at peak flow $(r<0.8)$ shows that multiple processes including sulfide oxidation coupled to carbonate dissolution and carbonation of carbonates affected the water chemistry. During the peak flow season, two processes controlled the chemical weathering: at first melting of both the icings and snow, and subsequently sulfide oxidation in combination with carbonation of carbonates.

The late ablation season can be distinguished from the peak flow season by the rapid increase of ion concentrations that appeared on $11^{\text {th }}$ September. The flux of crustally derived ions such as $* \mathrm{SO}_{4}{ }^{2-}, * \mathrm{Na}^{+}, * \mathrm{Mg}^{2+}$ and total dissolved solids corrected for atmospheric input increased during the late ablation season (Table 6). A decreasing ablation rate in the basin reduces the dilution of solute by meltwater, resulting in favourable conditions for mineral dissolution in the proglacial zone and beneath the glacier.

Intercepts of the ion associations $\left[\mathrm{HCO}_{3}{ }^{-}\right.$vs. $\left.{ }^{*} \mathrm{SO}_{4}{ }^{2-}\right]$ and $\left[{ }^{*} \mathrm{Ca}^{2+}+* \mathrm{Mg}^{2+}\right.$ vs. $\left.{ }^{*} \mathrm{SO}_{4}{ }^{2-}\right]$ were $\sim 2$ times higher than 220 ueq $\mathrm{L}^{-1}$ (ranging from 418 to $447 \mu$ eq $\mathrm{L}^{-1}$ ) during early ablation and peak flow seasons, suggesting that simple hydrolysis is accompanied by additional processes at initial stage of chemical weathering. Organic carbon oxidation can lead to the rise of the intercept of these regression equations by delivering $\mathrm{H}^{+}$that dissolves carbonates (Tranter et al., 2002). However, compared to other glacierised basins the organic carbon pool $\left(5 \mathrm{~g} \mathrm{~kg}^{-1}\right)$ in the sediments at our site is rather low with a low increasing gradient along the chronosequence (Kabala and Zapart, 2012). Thus, it is likely that organic matter oxidation has a limited influence on the water chemistry of Werenskioldbreen. Nevertheless, the thick sediment cover in proglacial zone may promote the microbial production of $\mathrm{CO}_{2}$ leading to higher intercepts for ion associations $\left[\mathrm{HCO}_{3}{ }^{-}\right.$vs. $\left.{ }^{*} \mathrm{SO}_{4}{ }^{2-}\right]$ and $\left[{ }^{*} \mathrm{Ca}^{2+}+* \mathrm{Mg}^{2+}\right.$ vs. $\left.{ }^{*} \mathrm{SO}_{4}{ }^{2-}\right]($ Fig. 6, Table 8, Wadham et al. 2010). Alternatively, re-dissolution of calcite rich proglacial 
603

604

605

606

607

608

609

610

611

612

613

614

615

616

617

618

619

620

621

622

623

624

625

626

sediment, driven by atmospheric $\mathrm{CO}_{2}$, is another potential explanation for elevated intercepts.

Proglacial calcite precipitation may lead to high content of calcite (up to 47\%) in the vicinity of naled ice assemblages (Bukowska-Jania, 2007) and thereby be a significant source of $\mathrm{HCO}_{3}$ and ${ }^{*} \mathrm{Ca}^{2+}$, particularly during the early ablation and peak flow seasons.

There is increasing chemical weathering along the chronosequence due to increasing vegetation cover, and the results indicate that divalent ions (especially $\mathrm{Ca}^{2+}$ ) are leached more readily than monovalent ions (primarily $\mathrm{Na}^{+}$), in agreement with previous studies (Moulton et al., 2000; Egli et al., 2001; Mavris et al., 2010). Therefore, divalent ions are rapidly depleted from the sediments close to the glacier front. Similarly, Kabala and Zapart (2012) observed a decreasing trend in exchangeable $\mathrm{Ca}^{2+}$ from younger sediments freshly uncovered in front of the glacier to 80 year-old soils in the proglacial area of Werenskioldbreen. An increase of the cation exchange capacity along chronosequences from freshly exposed sediment to older proglacial soils has also been observed (Bernasconi et al., 2011). Organic matter content increase is related to vegetation, and enhanced silicate weathering may be responsible for an increase of ion exchange capacity in older soils (Egli et al., 2001; Egli et al., 2006; Mavris et al., 2010; Mavris et al., 2012). Silicate weathering may lead to formation of secondary minerals in the proglacial area such as allophane, illite or kaolinite (Yde et al., 2005; Mavris et al., 2010; Vilmundardóttir et al., 2014). Although silicate weathering, organic matter content and vegetation cover area increase in the proglacial area of Werenskioldbreen (Piroznikow and Gorniak, 1992; Kabala and Zapart, 2012), the chemical weathering rate is still low due to the short time of 80 years since deglaciation (Kabala and Zapart, 2012). There is also no direct evidence of secondary clay mineral formation in the proglacial area of Werenskioldbreen, although the contents of silicate minerals such as amphibolite and mica decrease along the chronosequence (Kabala and Zapart, 2012). Additionally, soil pH 
627 decreases from younger to older sediments due to decay of plant residues (Kabala and Zapart, 628 2012).

629

\subsection{Chemical weathering under subglacial conditions}

At Kvisla, the regression slopes for the ion associations $\left[* \mathrm{Ca}^{2+}+* \mathrm{Mg}^{2+}\right.$ vs. $\left.{ }^{*} \mathrm{SO}_{4}{ }^{2-}\right],\left[\mathrm{HCO}_{3}{ }^{-} \mathrm{vs}\right.$. $\left.{ }^{*} \mathrm{SO}_{4}{ }^{2-}\right]$ and $\left[{ }^{*} \mathrm{Ca}^{2+}+* \mathrm{Mg}^{2+}\right.$ vs. $\left.\mathrm{HCO}_{3}{ }^{-}\right]($Table 8 , Fig. 6) are close to the theoretical slopes of sulfide oxidation coupled to carbonate dissolution and far from the slope for carbonation (Tranter et al., 2002). The lack of outliers in the regression and the strong correlations exceeding $\mathrm{r}=0.9$ in all ion associations indicate that sulfide oxidation coupled to carbonate dissolution prevailed during the ablation season. Interestingly, Kvisla appears to be sourced from a channelised system, where carbonation by atmospheric $\mathrm{CO}_{2}$ due to turbulent flow is expected to dominate (Mitchell and Brown, 2008). However, since sulfide oxidation coupled to carbonate dissolution prevails, the water at Kvisla must be primarily derived from a distributed drainage system with long residence time of water and high rock-to-water ratio. Similar controls have previously been invoked to explain changes in water chemistry in a channelised system during a high ablation event (Lamb et al., 1995). Hydrogeological modelling by Piechota et al. (2012) showed that Kvisla collects the ablation water from many

644 small tributaries. Also, high ${ }^{222} \mathrm{Rn}$ concentrations in the main outflows showed a long 645 residence time of meltwater in subglacial sediment, without atmospheric contact (Kies et al., 646 2011).

The Dusan outflow exhibits slopes different from sulfide oxidation coupled to carbonate dissolution, indicating the occurrence of additional chemical processes (Table 8, Fig. 6). The slopes of ion associations $\left[{ }^{*} \mathrm{Ca}^{2+}+* \mathrm{Mg}^{2+}\right.$ vs. $\left.\mathrm{HCO}_{3}{ }^{-}\right](\sim 2,0)$ and $\left[\mathrm{HCO}_{3}{ }^{-}\right.$vs. $\left.{ }^{*} \mathrm{SO}_{4}{ }^{2-}\right](\sim 1.3)$ reveal the dominance of sulfide oxidation coupled to dissolution of carbonates

651 occurring along the flow path of the Dusan outflow. Nearly $30 \%$ excess of $\mathrm{HCO}_{3}{ }^{-}$over $\mathrm{SO}_{4}{ }^{2-}$ 
652 in the former ion association suggests that an additional process enriched the water with

$653 \mathrm{HCO}_{3}{ }^{-}$. Microbial respiration enriching water in $\mathrm{CO}_{2}$ under slow water flow conditions, as 654 proposed by Wadham et al. (2010), seems insufficient to explain the significant excess of $655 \mathrm{HCO}_{3}{ }^{-}$observed here. The outflow regime in the vicinity of Dusan is characterised by a quick 656 response to ablation and high precipitation events (Krawczyk, 1992) and hence the turbulent 657 flow hinders microbial respiration. The excess of $\mathrm{HCO}_{3}{ }^{-}$and the slope of the ion association $658\left[{ }^{*} \mathrm{Ca}^{2+}+* \mathrm{Mg}^{2+}\right.$ vs. $\left.\mathrm{HCO}_{3}^{-}\right]$close to 1.0 support the occurrence of carbonation as an additional 659 chemical reaction. The short flow path in the central part of the glacier favours the potential 660 for carbonation. Another possible explanation of the slope of $\left[{ }^{*} \mathrm{Ca}^{2+}+* \mathrm{Mg}^{2+}\right.$ vs. $\left.\mathrm{HCO}_{3}^{-}\right]$is an 661 ion exchange that leads to a decrease in divalent ions compared to monovalent ions. The 662 concentrations of $* \mathrm{Ca}^{2+}$ and $* \mathrm{Mg}^{2+}$ were lower than at other sites (Fig. 6), whereas the 663 concentrations of $\mathrm{Na}^{+}$and $\mathrm{K}^{+}$were higher (Table 4). As the local bedrock consists of silicate 664 minerals (i.e. albite) (Czerny et al., 1992; Czerny et al., 1993), ion exchange and silicate 665 weathering are likely processes.

$666 \quad \mathrm{High} \mathrm{SiO}_{2}$ concentration compared to other sites suggests enhanced chemical 667 weathering of silicates (Table 4). However, it is difficult to distinguish between the relative 668 importance of each process because both microbial respiration and ion exchange can lower 669 the concentrations of divalent ions. Nevertheless, the high ratio of exchangeable $\mathrm{Ca}: \mathrm{Na}$ in 670 recently exposed sediments from Werenskioldbreen observed by Kabala and Zapart (2012) 671 indicates a high ion exchange capacity. Ion exchange affects the water chemistry significantly 672 in other glacierized basin as well (e.g. Graly et al. 2014, Wadham et al. 1998). Despite the 673 dominance of sulfide oxidation, the short residence time of water in the subglacial upwelling 674 system favours additional reactions such as carbonation and ion exchange occurring along the 675 flow path. This interpretation contradicts with the common assumption that proglacial 
upwellings are connected to a drainage system with long residence time of water and limited carbonation by atmospheric $\mathrm{CO}_{2}$ (Wadham et al., 2010a, b).

The Black spring showed the lowest slopes for all ion associations (Fig. 6, Table 8).

Despite of a slope of $\sim 0.9$ for the ion association $\left[\mathrm{HCO}_{3}{ }^{-} \mathrm{vs} .{ }^{*} \mathrm{SO}_{4}{ }^{2-}\right]$ that suggests sulfide oxidation coupled to carbonation of carbonates, the slope of $\left[{ }^{*} \mathrm{Ca}^{2+}+* \mathrm{Mg}^{2+}\right.$ vs. $\left.{ }^{*} \mathrm{SO}_{4}{ }^{2-}\right]$ below 1.4 indicates the presence of additional geochemical weathering processes. These are most likely due to carbonation, $\mathrm{Ca}$ and $\mathrm{Mg}$ efflorescent salt dissolution, simple hydrolysis and oxidation of organic matter. Although the slope of the ion association $\left[{ }^{*} \mathrm{Ca}^{2+}+* \mathrm{Mg}^{2+} \mathrm{vs}\right.$. $\left.\mathrm{HCO}_{3}{ }^{-}\right]$is close to the level expected for carbonation, the slope of the ion association $\left[\mathrm{HCO}_{3}{ }^{-}\right.$ vs. $\left.{ }^{*} \mathrm{SO}_{4}{ }^{2-}\right]$ is close to 1.0 indicating sulfide oxidation coupled to carbonate dissolution (Lamb et al., 1995). However, the surplus of $\mathrm{SO}_{4}{ }^{2-}$ could be partly explained by the dissolution of $\mathrm{Ca}$ and $\mathrm{Mg}$ efflorescent salts, a process that would lower the slope of ion association $\left[{ }^{*} \mathrm{Ca}^{2+}+* \mathrm{Mg}^{2+}\right.$ vs. $\left.{ }^{*} \mathrm{SO}_{4}{ }^{2-}\right]$ towards 1.0 . Sulfuric acid provided by from sulfide oxidation dissolves Ca-Mg efflorescence salts. Low correlation coefficients $(\mathrm{r}<0.8)$ compared to subglacial outflows confirmed that multiple reactions control the chemical composition. Also, quick flow (Piechota et al., 2012) and a large channel size (2-3 m wide) after 25 years of functioning exhibit conditions of turbulent flow favouring carbonation accompanied by $\mathrm{Ca}$ and $\mathrm{Mg}$ efflorescent salt dissolution.

\subsection{Solute fluxes and chemical denudation}

During the peak flow and late ablation seasons the mean daily solute fluxes were high in comparison with the early ablation season (Table 6), due to the close relation between discharge and solute fluxes. From the early ablation season to the late ablation season the daily fluxes of $* \mathrm{SO}_{4}{ }^{2-}, * \mathrm{Mg}^{2+}, * \mathrm{Na}^{+}$and $* \mathrm{~K}^{+}$increased significantly. Total fluxes during peak flow and late ablation were similar to Ebba River (Szpikowski et al. 2014). The fluxes of $\mathrm{Ca}^{2+}$ 
and $\mathrm{HCO}_{3}{ }^{-}$were relatively stable between the peak flow and late ablation seasons. Rapid release of $\mathrm{Ca}^{2+}$ and $\mathrm{HCO}_{3}{ }^{-}$from the surface of suspended sediments has been reported by Brown et al. (1996) and Gíslason et al. (2006) and induced the highest load of these ions during the peak flow season (Table 6). From the early ablation season to the peak flow season the yields of $\mathrm{Ca}^{2+}$ and $\mathrm{HCO}_{3}{ }^{-}$increased by a factor of $3-4$, the concentration of $* \mathrm{Ca}^{2+}$ decreased by a factor of two at the highest discharges, and $* \mathrm{Mg}^{2+}$ showed a five-fold decline (Fig. 5). Also, modest decreases in $\mathrm{Ca}^{2+}$ and $\mathrm{HCO}_{3}{ }^{-}$were observed compared to other ions (Table 5). These changes are in accordance with the low slope of ion association $\left[{ }^{*} \mathrm{Ca}^{2+}+* \mathrm{Mg}^{2+}\right.$ vs. $\left.\mathrm{HCO}_{3}{ }^{-}\right]$at the peak flow season, although the rates of $\mathrm{HCO}_{3}{ }^{-}$and $\mathrm{Ca}^{2+}$ release from suspended sediments vary depending mostly on the discharge. The fluxes of many ions $\left(* \mathrm{SO}_{4}{ }^{2-}, * \mathrm{~K}^{+}, * \mathrm{Na}^{+}\right.$and $\left.* \mathrm{Mg}^{2+}\right)$ showed a pronounced increase during the ablation season (Table 6). The vast amount of ablation water dilutes solutes sourced from the most active sites of chemical weathering (groundwater in the proglacial area or meltwater in the distributed subglacial system). Increase in the $* \mathrm{Na}^{+}$and $* \mathrm{~K}^{+}$fluxes can be attributed to the enhancement of chemical weathering of silicates or ion exchange, which takes place as a consequence of long residence time of meltwater and high rock:water ratio (e.g. Tranter et al., 1993; Anderson, 2005; Hindshaw et al., 2014). During the early ablation season, hydrogen ions released from snowmelt may be exchanged for divalent cations (Clow and Mast, 2010). When the amount of snowmelt abates, ion exchange on the silicate minerals surfaces releases $\mathrm{Na}^{+}$and $\mathrm{K}^{+}$to the solution and adsorbs divalent ions on the exchange surface (Table 6). Despite being within the range of the previously noted sulfate fluxes by Szynkiewicz et al. (2013), our results show a clear seasonal increase of sulfate fluxes that suggests increasing sulfide oxidation along with ablation season progress. Sulfide oxidation is known to be a donor of $\mathrm{H}^{+}$to the chemical weathering of silicates and carbonates. This is in accordance with the results showing that the fluxes of the silicate-derived ions 
726

727

728

729

730

731

732

733

734

735

736

737

$\left({ }^{*} \mathrm{Na}^{+},{ }^{*} \mathrm{~K}^{+}\right)$are considerably lower than carbonate-sourced ion $\left({ }^{*} \mathrm{Ca}^{2+}\right)$. Simultaneous release of ions and dissolved silica is often related to chemical weathering of silicates (Tranter et al, 2002), but the flux of $* \mathrm{Mg}^{2+}$ is higher than the dissolved silica flux (Table 6). This could be explained by incongruent chemical weathering of silicates, which form secondary minerals (i.e. kaolinite, Eq. (5)) or weathered silicate surfaces (Eq. (11)). Alternatively, dissolved silica flux could be related to the dissolution of $\mathrm{Na}-\mathrm{K}$ bearing silicates (i.e. albite or muscovite). Nevertheless, a high load of dolomite transported as suspended sediments and pronounced leaching of dolomite in the proglacial area indicate that the dissolution of dolomite is a major source of $* \mathrm{Mg}^{2+}$ (Bukowska-Jania, 2007; Kabala and Zapart, 2012).

The CDR of $1601 \mathrm{meq} \mathrm{m}^{-2} \mathrm{yr}^{-1}$ in the Werenskioldbreen basin is considerably higher than in other glacierised basins in Svalbard (Hodson et al., 2000). The previous comprehensive work from Werenskioldbreen on the chemical denudation is from 1979-1980 and 1986 (Pulina et al., 1984; Krawczyk et al., 2003) and revealed $25 \%$ and $\sim 18 \%$ lower denudation rates than was observed in 2011. Similar CDR have been found in glacierised basins situated in tectonically active areas in the Himalayas (Batura Glacier 1560 meq m $\mathrm{m}^{-2} \mathrm{yr}^{-1}$ (Collins et al., 1996); Dokriani Glacier $4200 \mathrm{meq} \mathrm{m}^{-2} \mathrm{yr}^{-1}$ (Hasnain and Thayyen, 1999)), in Iceland (Hvita-south Gulfos 1100 meq m$^{-2} \mathrm{yr}^{-1}$ (Gíslason, 1996)) and in Alaska (Worthington Glacier $1600 \mathrm{meq} \mathrm{m}^{-2} \mathrm{yr}^{-1}$ (Anderson et al., 1997)). Conversely, chemical denudation rates below 500 meq $\mathrm{m}^{-2} \mathrm{yr}^{-1}$ have been reported in Svalbard (Vatne et al., 1995; Wadham et al., 1998; Hodson et al., 2000; Yde et al., 2008) and the previous maximum CDR in the archipelago was $713 \mathrm{meq} \mathrm{m}^{-2} \mathrm{yr}^{-1}$ in the Scottbreen basin (Krawczyk and Bartoszewski, 2008). This implies that the Werenskioldbreen basin is extremely active from a chemical denudation perspective and that chemical denudation in Svalbard could be higher than previously thought. However, the relatively high runoff from the Werenskioldbreen basin exceeds runoff at other study sites (Hodson et al., 2000). The specific annual runoff from 
751 glacierised basins in Svalbard tends to be below 1 m (Hodgkins et al., 1997; Hodson et al.,

752 2000; Yde et al., 2008), while in the Werenskioldbreen basin it exceeds $1.8 \mathrm{~m}$ (Table 7). It is

753 therefore very likely that the high rate of chemical denudation is primarily due to high

754 discharge and secondarily high chemical weathering rates. This assessment is supported by

755 comparison to other glacierised basins in Svalbard with similar water chemistry composition

756 (Wadham et al., 1997; Hodson et al., 2002; Szpikowski et al. 2014). When CDR is normalised

757 by runoff, the Werenskioldbreen basin chemical denudation rate is only slightly higher than in

758 other Svalbard basins. Similar runoff-normalised CDR was noted for Scottbreen (Krawczyk

759 and Bartoszewski, 2008) and Longyearbreen (Yde et al., 2008). Solutes derived from

760 snowmelt were calculated from the marine ratio and was excluded from total solute yields by

761 sea-salt correction of water chemistry.

762

763

764

765

ablation season at Werenskioldbreen, a polythermal land-terminating glacier situated in

766

767

768

769

770

771

772

773

774

775

\section{Conclusions}

This work presents a hydrochemical, hydrological and ablation dataset covering an entire Svalbard. The major findings show:

- $\quad$ higher chemical denudation rates than previously reported from Svalbard glaciers. This is primarily due to high rates of ablation and runoff rather than higher chemical weathering intensities. The rate of chemical denudation in the Werenskioldbreen basin in 2011 was among the highest recorded for a glacierised basin worldwide, reaching 1601 meq $\mathrm{m}^{-2} \mathrm{yr}^{-1}$ (or $121.9 \mathrm{t} \mathrm{km}^{-2} \mathrm{yr}^{-1}$ ). This was caused by a high specific annual runoff of $1.8 \mathrm{~m}$, which enabled transport of a substantial amount of dissolved solutes;

the first annual record from a glacierized catchment showing re-dissolution of calcite driven by atmospheric $\mathrm{CO}_{2}$ during the early ablation and peak flow seasons, causing elevated concentrations of $\mathrm{Ca}^{2+}$ and $\mathrm{HCO}_{3}{ }^{-}$in the proglacial zone and high fluxes of $\mathrm{Ca}^{2+}$ and 
$\mathrm{HCO}_{3}{ }^{-}$during the peak flow season. This also shows that organic matter oxidation may not play an important role in carbonate dissolution in young proglacial zones ( $\sim 80$ years).

Throughout the ablation season, continuous leaching of calcium carbonate in the proglacial zone caused a drop in intercepts of the ion associations $\left[\mathrm{HCO}_{3}{ }^{-}\right.$vs. $\left.{ }^{*} \mathrm{SO}_{4}{ }^{2-}\right]$ and $\left[{ }^{*} \mathrm{Ca}^{2+}+* \mathrm{Mg}^{2+}\right.$ vs. $\left.{ }^{*} \mathrm{SO}_{4}{ }^{2-}\right]$ from between 418 and $447 \mu \mathrm{eq} \mathrm{L}^{-1}$ to values typical for simple hydrolysis $(220$ $\mu$ eq $\mathrm{L}^{-1}$ ). Hence, the proglacial dissolution of calcium carbonate by atmospheric $\mathrm{CO}_{2}$ may be more important to proglacial solute fluxes than biological activity;

- that sulfide oxidation is a better parameter for determination of the drainage system configuration for small polythermal glacier (short water residence time when compared to large glacier and ice sheets) than the previously used concentrations of $\mathrm{Na}^{+}$and $\mathrm{K}^{+}$. Sulfide oxidation coupled to dissolution of carbonates dominates in the distributed subglacial drainage system characterized by long flow paths. In contrast, silicate dissolution is related to the more discrete subglacial drainage system characterized by short flow paths.

These findings contradict with the common assumption that relatively slow silicate weathering is related to distributed subglacial drainage systems.

Our study of Werenskioldbreen indicates that at small glaciers with relatively low water residence time and presence of sulfide and carbonate minerals, sulfide oxidation coupled with carbonate dissolution predominates. This is likely to be in contrast to larger glaciers, where sulfide oxidation coupled to silicate weathering becomes important. Future progress should focus on advancing our understanding of the dynamics of chemical denudation in glacierised basin by coupling water chemistry with estimations of glacier ablation rates, runoff and subglacial storage. Water sampling should be performed more extensively during the early and late ablation seasons when elevated ion concentrations are observed. 
801

802

803

804

805

806

807

808

809

810

811

812

813

814

815

816

817

818

819

820

821

822

823

824

825

\section{Acknowledgements}

The authors are thankful to Zbigniew Sobierajski from the Polish Polar Station in Hornsund for conducting the IC analyses, and Wieslaw Knap from the Hydrogeochemical Laboratory at the University of Science and Technology in Krakow for conducting the ICP-OES analyses.

We are also grateful to Joanna Szafraniec and Jarosław Hałat for discharge measurements, water sampling and help during the fieldwork; while the Director of the Institute of

Geography and Regional Development in the University of Wrocław, Professor Piotr Migon, is acknowledged for permitting our stay at the Polish Polar Station of University of Wrocław on Spitsbergen. This work was supported by two research projects: N N306 792040 and N N306 179737, both funded from the Polish National Science Foundation. We are grateful for the thorough reviews provided by three anonymous reviewers and Associate Editor Melissa Lafrenière.

\section{References}

Anderson, S.P., Drever, J.I., Humphrey, N.F., 1997. Chemical weathering in glacial environments. Geology 25 (5), 399-402.

Anderson, S.P., Drever, J.I., Frost, C.D., Holden, P., 2000. Chemical weathering in the foreland of a retreating glacier. Geochim. Cosmochim. Acta 64 (7), 1173-1189. Anderson, S.P., 2005. Glaciers show direct linkage between erosion rate and chemical weathering fluxes. Geomorphology 67(1-2 SPEC. ISS.), 147-157.

Anderson, S. P., 2006. Impact of Mineral Surface Area on Solute Fluxes at Bench Glacier, Alaska, in: Knight, P.G. (Ed.), Glacier Science and Environmental Change. Blackwell Publishing, Malden, USA, pp. 79-81.

Appelo, A., Postma, D., 2005. Geochemistry, groundwater and pollution. $2^{\text {nd }}$ edition. Balkema Publishers, Amsterdam, the Netherlands, 649 pp. 
Bania, M., Wawrzyniak, T., 2011a. Meteorological bulletin Spitsbergen - Hornsund October 2011. Polish Polar Station Institute of Geophysics Polish Academy of Sciences, Hornsund, Norway.

Bania, M., Wawrzyniak, T., 2011b. Meteorological bulletin Spitsbergen - Hornsund June 2011. Polish Polar Station Institute of Geophysics Polish Academy of Sciences, Hornsund, Norway.

Bania, M., Wawrzyniak, T., 2011c. Meteorological bulletin Spitsbergen - Hornsund August 2011. Polish Polar Station Institute of Geophysics Polish Academy of Sciences, Hornsund, Norway.

Bania, M., Wawrzyniak, T., 2011d. Meteorological bulletin Spitsbergen - Hornsund September 2011. Polish Polar Station Institute of Geophysics Polish Academy of Sciences, Hornsund, Norway.

Bania, M., Wawrzyniak, T., 2011e. Meteorological bulletin Spitsbergen - Hornsund July 2011. Polish Polar Station Institute of Geophysics Polish Academy of Sciences, Hornsund, Norway.

Bernasconi, S.M. et al., 2011. Chemical and biological gradients along the damma glacier soil chronosequence, Switzerland. Vadose Zone J. 10(3), 867-883.

Brown, G.H., Sharp, M.J., Tranter, M., Gurnell, A.M., Nienow, P.W., 1994. Impact of postmixing chemical reactions on the major ion chemistry of bulk meltwaters draining the Haut Glacier d'Arolla, Valais, Switzerland. Hydrol. Processes 8 (5), 465-480.

Brown, G.H., Tranter, M., Sharp, M.J., 1996. Experimental investigations of the weathering of suspended sediment by alpine glacial meltwater. Hydrol. Processes 10 (4), 579597.

Brown, G.H., 2002. Glacier meltwater hydrochemistry. Appl. Geochem. 17 (7), 855-883. 
Bukowska-Jania, E., 2007. The role of glacier system in migration of calcium carbonate on Svalbard. Pol. Polar Res. 28 (2), 137-155.

Clow, D.W., Mast, M.A., 2010. Mechanisms for chemostatic behavior in catchments: Implications for $\mathrm{CO}_{2}$ consumption by mineral weathering. Chem. Geol. 269 (1-2), 4051.

Collins, D.N., Lowe, A., Boult, S., 1996. Solute fluxes in meltwaters draining from glacierised high mountain basins. Fourth International Symposium on the Geochemistry of the Earth's Surface, Ilkley, United Kingdom, pp. 728-732.

Cooper, R.J., Wadham, J.L., Tranter, M., Hodgkins, R., Peters, N.E., 2002. Groundwater hydrochemistry in the active layer of the proglacial zone, Finsterwalderbreen, Svalbard. J. Hydrol. 269 (3-4), 208-223.

Czerny, J., Lipien, G., Manecki, A., Piestrzynski, A., 1992. Geology and ore-mineralization of the Hecla Hoek Succession (Precambrian) in front of Werenskioldbreen, south Spitsbergen. Stud. Geol. Pol. 98, 67-113.

Czerny, J., Kieres, A., Manecki, M., Rajchel, J., 1993. Geological Map of the SW Part of Wedel-Jarlsberg Land, Spitsbergen, in: Manecki, A. (Editor). Institute of Geology and Mineral Deposits, University of Mining and Metallurgy, Kraków, Poland.

Egli, M., Fitze, P., Mirabella, A., 2001. Weathering and evolution of soils formed on granitic, glacial deposits: Results from chronosequences of Swiss alpine environments. Catena 45(1), 19-47.

Egli, M., Wernli, M., Kneisel, C., Haeberli, W., 2006. Melting glaciers and soil development in the proglacial area Morteratsch (Swiss Alps): I. Soil type chronosequence. Arctic, Antarctic, and Alpine Research, 38(4), 499-509. 
873 Fairchild, I.J., Killawee, J.A., Sharp, M.J., Spiro, B., Hubbard, B., Lorrain, R.D., Tison, J.L., 874 1999. Solute generation and transfer from a chemically reactive alpine glacial875 proglacial system. Earth Surf. Proc. Land. 24 (13), 1189-1211.

876 Geng, H., Jiyeon, R., Jung, H.-J., Chung, H., Ahn, K.-H., Ro, C.-U., 2010. Single-particle 877 characterization of summertime Arctic aerosols collected at Ny-Ålesund, Svalbard. 878 Environ. Sci. Technol. 44 (7), 2348-2353.

879 Gibs, J., Wilde, F.D., Heckathorn, H.A., 2007. Use of multiparameter instruments for routine 880 field measurements (ver 1.1), : U.S. Geological Survey Techniques of WaterResources Investigations, book 9, chapter A6, section 6.8.

Gíslason, S.D.S.R., Arnórsson, S., Ármannsson, H., 1996. Chemical weathering of basalt in Southwest Iceland: Effects of runoff, age of rocks and vegetative/glacial cover. Am. J. Sci. $296(8), 837-907$.

Gíslason, S.R., Oelkers, E.H., Snorrason, Á., 2006. Role of river-suspended material in the global carbon cycle. Geology 34 (1), 49-52. doi: 10.1130/G22045.1

Głowicki, B., 1982. Some hydrological phenomena observed in the outflow from the Werenskiold glacier basin. A. Univ. Wratislaviensis 4, 49-56.

Grabiec, M., Budzik, T., Głowacki, P., 2012. Modeling and hindcasting of the mass balance of werenskioldbreen (Southern Svalbard). Arctic Anatarctic and Alpine Research 44 (2), 164-179.

Graly, J.A., Humphrey, N.F., Landowski, C.M., Harper, J.T., 2014. Chemical weathering under the Greenland ice sheet. Geology, 42(6), 551-554.

Hagen, J.O., Liestol, O., Roland, E., Jorgensen, T., 1993. Glacier atlas of Svalbard and Jan Mayen. Meddelelser nr. 129. Norsk Polarinstitutt, Oslo. 
Hallet, B., Hunter, L., Bogen, J., 1996. Rates of erosion and sediment evacuation by glacier: A review of field data and their implications. Global and Planetary Change 12, 213235.

Hasnain, S.I., Thayyen, R.J., 1999. Controls on the major-ion chemistry of the Dokriani glacier meltwaters, Ganga basin, Garhwal Himalaya, India. J. Glaciol. 45 (149), $87-$ 92.

Hawkings, J.R., Wadham, J.L., Tranter, M., Raiswell, R., Benning, L.G., Statham, P.J., Tedstone, A., Nienow, P., Lee, K., Telling, J., 2014. Ice sheets as a significant source of highly reactive nanoparticulate iron to the oceans. Nat. Commun. 5 (3929), 1-8.

Hindshaw, R.S., Tipper, E.T., Reynolds, B.C., Lemarchand, E., Wiederhold, J.G., Magnusson, J., Bernasconi, S.M., Kretzschmar, R., Bourdon, B., 2011. Hydrological control of stream water chemistry in a glacial catchment (Damma Glacier, Switzerland). Chem. Geol. 285 (1-4), 215-230.

Hindshaw, R.S., Rickli, J., Leuthold, J., Wadham, J., Bourdon, B., 2014. Identifying weathering sources and processes in an outlet glacier of the Greenland Ice Sheet using $\mathrm{Ca}$ and Sr isotope ratios. Geochimica et Cosmochimica Acta 145, 50-71.

Hodgkins, R., Tranter, M., Dowdeswell, J.A., 1997. Solute provenance, transport and denudation in a High Arctic glacierized catchment. Hydrol. Processes 11 (14), 18131832.

Hodson, A., Tranter, M., Vatne, G., 2000. Contemporary rates of chemical denudation and atmospheric $\mathrm{CO} 2$ sequestration in glacier basins: An arctic perspective. Earth Surf. Proc. Land. 25 (13), 1447-1471.

Hodson, A., Tranter, M., Gurnell, A., Clark, M., Hagen, J.O., 2002. The hydrochemistry of Bayelva, a high Arctic proglacial stream in Svalbard. J. Hydrol. 257 (1-4), 91-114. 
Holland, H.D., 1978. The chemistry of the atmosphere and oceans. Wiley Intersciece, New York, $351 \mathrm{pp}$.

Ignatiuk, D., 2012. Bilans energetyczny powierzchni lodowca a zasilanie systemu drenażu glacjalnego Werenskioldbreen [The energy balance of the glacier surface and water supply of drainage system of Werenskioldbreen]. PhD Thesis, Sosnowiec, Poland, $178 \mathrm{pp}$.

Ignatiuk, D., Migała, K., 2013. Werenskiold Glacier, in: Zwoliński, Z., Kostrzewski, A., Pulina, M. (Eds.), Ancient and modern geoecosystems of Spitsbergen. Association of Polish Geomorphologists, Poznań, Poland, pp. 96-99.

Irvine-Fynn, T.D.L., Hodson, A.J., Moorman, B.J., Vatne, G., Hubbard, A.L., 2011. Polythermal glacier hydrology: A review. Rev. Geophys. 49 (4), RG4002.

Kabala, C., Zapart, J., 2012. Initial soil development and carbon accumulation on moraines of the rapidly retreating Werenskiold Glacier, SW Spitsbergen, Svalbard archipelago. Geoderma 175-176, 9-20.

Kieres, A., Piestrzynski, A., 1992. Ore-mineralization of the Hecla Hoek Succession (Precambrian) around Werenskioldbreen, south Spitsbergen. Stud. Geol. Pol. 98, 115151.

Kies, A., Nawrot, A., Tosheva, Z., Jania, J., 2011. Natural radioactive isotopes in glacier meltwater studies. Geochem. J. 45(6), 423-429.

Kowalska, A., Soroka, W., 2008. Sedimentary environment of the Nottinghambukta delta, SW Spitsbergen. Polish Polar Res. 29(3), 245-259.

Krawczyk, W., Wach, J., 1993. Winter outflow of waters from the Werenskiold glacier in the hydrological year 1985/1986, in: Repelewska-Pekalowa, J., Pękala, K. (Eds.), XX Polar Symposium Main impact on polar environment, Lublin, Poland, pp. 403-411. 
944 Krawczyk, W., Opołka-Gądek, J., 1994. Suspended sediment concentration in the

Werenskiold glacier drainage basin in 1986, in: Zalewski, M.S. (Ed.), XXI Polar symposium, Warszawa, Poland, pp. 215-224.

Krawczyk, W.E., 1992. Chemical characteristics of water circulating in the Werenskiold Glacier (SW Spitsbergen), 2nd International Symposium of Glacier Caves and Karst in Polar Regions, Sosnowiec, Poland, pp. 65-80.

Krawczyk, W.E., Lefauconnier, B., Pettersson, L.E., 2003. Chemical denudation rates in the Bayelva Catchment, Svalbard, in the Fall of 2000. Phys. Chem. Earth 28 (28-32), $1257-1271$.

Krawczyk, W.E., Bartoszewski, S.A., 2008. Crustal solute fluxes and transient carbon dioxide drawdown in the Scottbreen Basin, Svalbard in 2002. J. Hydrol. 362 (3-4), 206-219.

Kristiansen, S.M., Yde, J.C., Bárcena, T.G., Jakobsen, B.H., Olsen, J., Knudsen, N.T., 2013. Geochemistry of groundwater in front of a warm-based glacier in Southeast Greenland. Geogr. Ann. A 95 (2), 97-108.

Lamb, H.R., Tranter, M., Brown, G.H., Hubbard, B.P., Sharp, M.J., Gordon, S., Smart, C.C., Willis, C.C., Nielsen, K., 1995. The composition of subglacial meltwaters sampled from boreholes at Haut Glacier d'Arolla Switzerland. IAHS Publ. 228, 395-403.

Majchrowska, E., Małarzewski, Ł., 2011. Meteorological bulletin Spitsbergen - Hornsund May 2011, Polish Polar Station Institute of Geophysics Polish Academy of Sciences, Hornsund, Norway.

Majchrowska, E., Cichała-Kamrowska, K., 2013. The dynamics of suspended sediment transport in a glaciated catchment at the beginning of the ablation season 2011 (Werenskioldbreen, Spitsbergen). The dynamics and mass budget of Arctics glaciers IASC Network on Arctic Glaciology, pp. 35-38. 
Majchrowska E., Ignatiuk D., Jania J., Marszałek H., Wąsik M., 2015. Seasonal and interannual variability in runoff from the Werenskioldbreen catchment, Spitsbergen. Polish Polar Res. 36(3), 197-224.

Mavris, C., Egli, M., Plötze, M., Blum, J.D., Mirabella, A., Giaccai, D., Haeberli, W., 2010. Initial stages of weathering and soil formation in the Morteratsch proglacial area (Upper Engadine, Switzerland). Geoderma 155(3-4), 359-371.

Mavris, C., Götze, J., Plötze, M., Egli, M., 2012. Weathering and mineralogical evolution in a high Alpine soil chronosequence: A combined approach using SEM-EDX, cathodoluminescence and Nomarski DIC microscopy. Sediment. Geol. 280, 108-118.

Mitchell, A.C., Brown, G.H., 2008. Modeling geochemical and biogeochemical reactions in subglacial environments. Arctic Anatarctic and Alpine Research 40 (3), 531-547.

Moulton, K.L., West, J., Berner, R.A., 2000. Solute flux and mineral mass balance approaches to the quantification of plant effects on silicate weathering. American Journal of Science 300(7), 539-570.

Mitchell, A.C., Lafrenière, M.J., Skidmore, M.L., Boyd, E.S., 2013. Influence of bedrock mineral composition on microbial diversity in a subglacial environment. Geology, 41(8): 855-858.

Nienow, P., Sharp, M., Willis, I., 1998. Seasonal changes in the morphology of the subglacial drainage system, Haut Glacier d'Arolla, Switzerland. Earth Surf. Proc. Land. 23 (9), $825-843$.

Nowak, A., Hodson, A., 2013. Hydrological response of a High-Arctic catchment to changing climate over the past 35 years: A case study of Bayelva watershed, Svalbard. Polar Research, 32(SUPPL.). 
991

992

993

994

995

996

997

998

999

1000

1001

1002

1003

1004

1005

1006

1007

1008

1009

1010

1011

1012

1013

1014

1015

Nowak, A., Hodson, A., 2014. Changes in meltwater chemistry over a 20 -year period following a thermal regime switch from polythermal to cold-based glaciation at Austre Brøggerbreen, Svalbard. Polar Res. 33, 22779, doi: 10.3402/polar.v33.22779.

Pälli, A., Moore, J.C., Jania, J., Kolondra, L., Głowacki, P., 2003. The drainage pattern of Hansbreen and Werenskioldbreen, two polythermal glaciers in Svalbard. Polar Res. 22 (2), 355-371.

Piechota, A.M., Sitek, S., Ignatiuk, D., Piotrowski, J.A., 2012. Reconstructing subglacial drainage of Werenskiold Glacier (SW Spitsbergen) based on numerical modelling. Rekonstrukcja drenażu subglacjalnego lodowca Werenskiolda (SW Spitsbergen) na podstawie modelowania numerycznego. Biuletyn Państwowego Instytutu Geologicznego 451, 191-202.

Piroznikow, E., Gorniak, A., 1992. Changes in the characteristics of the soil and vegetation during the primary succession in the marginal zone of the Werenskiold glacier, Spitsbergen. Polish Polar Research 13(1), 19-29.

Pulina, M., 1984. The effects of cryochemical processes in the glaciers and the permafrost in Spitsbergen. Pol. Polar Res. 5 (3-4), 137-163.

Pulina, M., Pereyma, J., Kida, J., Krawczyk, W., 1984. Characteristics of the polar hydrological year 1979/1980 in the basin of the Werenskiold Glacier, SW Spitzbergen. Pol. Polar Res. 5 (3-4), 165-182.

Pulina, M., Kolondra, L., Rehak, J., 1999a. Charting the cryocarst forms on Werenskiold Glacier (SW Spitsbergen), in: Repelewska-Pekalowa, J. (Ed.), Polish Polar Studies XXVI Polar Symposium, Lublin, Poland, pp. 235-241.

Pulina, M., Krawczyk, W.E., Galas, W., 1999b. Chemical characteristics of waters in the Hornsund Region in the summer of 1998, in: Repelewska-Pekalowa, J. (Ed.), Polish Polar Studies XXVI Polar Symposium, Lublin, Poland, pp. 243-250. 
Raiswell, R., Tranter, M., Benning, L.G., Siegert, M., De'ath, R., Huybrechts, P., Payne, T., 2006. Contributions from glacially derived sediment to the global iron (oxyhydr)oxide cycle: Implications for iron delivery to the oceans. Geochim. Cosmochim. Acta 70 (11), 2765-2780.

Rantz, S.E., 1982. Measurement and Computation of Streamflow vol 1: Measurement of stage and discharge. 2175. Geological Survey Water-Supply, Washington.

Rehak, J., Ouhrabka, V., Braun, J., 1990. New information about drainage of the subpolar glaciers and the structure of medial moraines in southwest Spitsbergen. Stud. Carsologica 1, 15-56.

Rutter, N., Hodson, A., Irvine-Fynn, T., Solås, M.K., 2011. Hydrology and hydrochemistry of a deglaciating high-Arctic catchment, Svalbard. J. Hydrol. 410 (1-2), 39-50.

Sharp, M., Tranter, M., Brown, G.H., Skidmore, M., 1995. Rates of chemical denudation and $\mathrm{CO}_{2}$ drawdown in a glacier-covered alpine catchment. Geology 23 (1), 61-64.

Singh, A.K., Hasnain, S.I., 2002. Aspects of weathering and solute acquisition processes controlling chemistry of sub-Alpine proglacial streams of Garhwal Himalaya, India. Hydrological Processes 16(4), 835-849.

Stachnik, L., Uzarowicz, L., 2011. The relationship between dissolved solids yield and the presence of snow cover in the Periglacial Basin of the Obruchev glacier (Polar Urals) during the ablation season. Quaestiones Geographicae 30 (1), 95-103.

Stachnik, Ł., Wałach, P., Uzarowicz, Ł., Yde, J.C., Tosheva, Z., Wrońska-Wałach, D., 2014. Water chemistry and hydrometeorology in a glacierized catchment in the Polar Urals, Russia. J. Mt. Sci. 11 (5), 1097-1111.

Szpikowski, J., Szpikowska, G., Zwoliński, Z., Rachlewicz, G., Kostrzewski, A., Marciniak, M., Dragon, K., 2014. Character and rate of denudation in a High Arctic glacierized catchment (Ebbaelva, Central Spitsbergen). Geomorphology 218, 52-62. 
1041

1042

1043

1044

1045

1046

1047

1048

1049

1050

1051

1052

1053

1054

1055

1056

1057

1058

1059

1060

1061

1062

1063

1064

1065

Szynkiewicz, A., Modelska, M., Buczyński, S., Borrok, D.M., Merrison, J.P., 2013. The polar sulfur cycle in the Werenskioldbreen, Spitsbergen: Possible implications for understanding the deposition of sulfate minerals in the North Polar Region of Mars. Geochim. Cosmochim. Acta 106, 326-343.

Tranter, M., Brown, G., Raiswell, R., Sharp, M., Gurnell, A., 1993. A conceptual model of solute acquisition by Alpine glacial meltwaters. J. Glaciol. 39 (133), 573-581.

Tranter, M., Brown, G.H., Hodson, A.J., Gurnell, A.M., 1996. Hydrochemistry as an indicator of subglacial drainage system structure: A comparison of alpine and sub-polar environments. Hydrol. Processes10 (4), 541-556.

Tranter, M., Sharp, M.J., Lamb, H.R., Brown, G.H., Hubbard, B.P., Willis, I.C., 2002. Geochemical weathering at the bed of Haut glacier d'Arolla, Switzerland - A new model. Hydrol. Processes 16 (5), 959-993.

Tranter, M., Wadham, J.L., 2013. Geochemical Weathering in Glacial and Proglacial Environments, Treatise on Geochemistry: Second Edition. Elsevier Inc., pp. 157-173.

Vatne, G., Etzelmuller, B., Sollid, J.L., Odegard, R.S., 1995. Hydrology of a polythermal glacier, Erikbreen, northern Spistbergen. Nord. Hydrol. 26 (3), 169-190.

Vilmundardóttir, O.K., Gísladóttir, G., Lal, R., 2014. Early stage development of selected soil properties along the proglacial moraines of Skaftafellsjökull glacier, SE-Iceland. Catena $121,142-150$.

Vinogradov, Y.B., Semenova, O.M., Vinogradova, T.A., 2011. An approach to the scaling problem in hydrological modelling: The deterministic modelling hydrological system. Hydrol. Processes 25 (7), 1055-1073.

Wadham, J.L., Hodson, A.J., Tranter, M., Dowdeswell, J.A., 1997. The rate of chemical weathering beneath a quiescent, surge-type, polythermal-based glacier, southern Spitsbergen, Svalbard. Ann. Glaciol. 24, 27-31. 
Wadham, J.L., Hodson, A.J., Tranter, M., Dowdeswell, J.A., 1998. The hydrochemistry of meltwaters draining a polythermal-based, high Arctic glacier, south Svalbard: I. The ablation season. Hydrol. Processes 12 (12), 1825-1849.

Wadham, J.L., Tranter, M., Dowdeswell, J.A., 2000. Hydrochemistry of meltwaters draining a polythermal-based, high-Arctic glacier, south Svalbard: II. Winter and early Spring. Hydrol. Processes 14 (10), 1767-1786.

Wadham, J.L., Cooper, R.J., Tranter, M., Hodgkins, R., 2001. Enhancement of glacial solute fluxes in the proglacial zone of a polythermal glacier. J. Glaciol. 47 (158), 378-386.

Wadham, J.L., Hodgkins, R., J., C.R., Tranter, M., 2001. Evidence for seasonal subglacial outburst events at a polythermal glacier, Finsterwalderbreen, Svalbard. Hydrol. Processes 15, 2259-2280.

Wadham, J.L., Bottrell, S., Tranter, M., Raiswell, R., 2004. Stable isotope evidence for microbial sulfate reduction at the bed of a polythermal high Arctic glacier. Earth Planet. Sc. Lett. 219 (3-4), 341-355.

Wadham, J.L., Cooper, R.J., Tranter, M., Bottrell, S., 2007. Evidence for widespread anoxia in the proglacial zone of an Arctic glacier. Chem. Geol. 243 (1-2), 1-15.

Wadham, J.L., Tranter, M., Hodson, A.J., Hodgkins, R., Bottrell, S., Cooper, R., Raiswell, R., 2010a. Hydro-biogeochemical coupling beneath a large polythermal Arctic glacier: Implications for subice sheet biogeochemistry. J. Geophys. Res. 115 (4), F04017.

Wadham, J.L., Tranter, M., Skidmore, M., Hodson, A.J., Priscu, J., Lyons, W.B., Sharp, M., Wynn, P., Jackson, M., 2010b. Biogeochemical weathering under ice: Size matters. Global Biogeochemical Cycles 24 (3), GB3025.

Yde, J.C., Knudsen, T.N., Nielsen, O.B., 2005. Glacier hydrochemistry, solute provenance, and chemical denudation at a surge-type glacier in Kuannersuit Kuussuat, Disko Island, West Greenland. J. Hydrol. 300 (1-4), 172-187. 
1091

1092

1093

1094

1095

1096

1097

1098

1099

1100

Yde, J.C., Riger-Kusk, M., Christiansen, H.H., Knudsen, N.T., Humlum, O., 2008.

Hydrochemical characteristics of bulk meltwater from an entire ablation season, Longyearbreen, Svalbard. J. Glaciol. 54 (185), 259-272.

Yde, J.C., Hodson, A.J., Solovjanova, I., Steffensen, J.P., Nørnberg, P., Heinemeier, J., Olsen, J., 2012. Chemical and isotopic characteristics of a glacier-derived naled in front of Austre Grønfjordbreen, Svalbard. Polar Res. 31 (SUPPL.).

Yde, J.C., Knudsen, N.T., Hasholt, B., Mikkelsen, A.B., 2014. Meltwater chemistry and solute export from a Greenland Ice Sheet catchment, Watson River, West Greenland. J. Hydrol. 519, 2165-2179. 
1101 Table 1. Mineral composition of bedrock, proglacial sediments and suspended sediment in the 1102 Werenskioldbreen basin.

\begin{tabular}{|c|c|c|c|}
\hline Major minerals & Position & $\begin{array}{l}\text { Type of } \\
\text { rock/sediments }\end{array}$ & Reference \\
\hline $\begin{array}{l}\text { Fe-dolomite, galena, pyrite, } \\
\text { quartz, sphalerite }\end{array}$ & $\begin{array}{l}\text { Outcrops in } \\
\text { southern part of } \\
\text { proglacial zone }\end{array}$ & $\begin{array}{l}\text { Bedrock - massive } \\
\text { sphalerite ore }\end{array}$ & Czerny et al., 1992 \\
\hline $\begin{array}{l}\text { Ankerite, barite, Fe-dolomite, } \\
\text { quartz }\end{array}$ & $\begin{array}{l}\text { Outcrops in } \\
\text { southern part of } \\
\text { proglacial zone }\end{array}$ & $\begin{array}{l}\text { Bedrock (southern } \\
\text { part) - carbonate } \\
\text { minerals from ore } \\
\text { veins }\end{array}$ & Czerny et al., 1992 \\
\hline $\begin{array}{l}\text { Albite, ankerite, chlorite, Fe- } \\
\text { dolomite, muscovite, quartz }\end{array}$ & $\begin{array}{l}\text { Outcrops in } \\
\text { southern part of } \\
\text { proglacial zone part }\end{array}$ & $\begin{array}{l}\text { Bedrock (southern } \\
\text { part) - muscovite- } \\
\text { carbonate-quartz } \\
\text { schists }\end{array}$ & Czerny et al., 1992 \\
\hline $\begin{array}{l}\text { Chlorite, chloritoid, muscovite, } \\
\text { paragonite, quartz }\end{array}$ & $\begin{array}{l}\text { Outcrops in } \\
\text { southern part of } \\
\text { proglacial zone part }\end{array}$ & $\begin{array}{l}\text { Bedrock (southern } \\
\text { part) - chloritoid- } \\
\text { bearing quartz mica } \\
\text { schists }\end{array}$ & Czerny et al., 1992 \\
\hline $\begin{array}{l}\text { Magnesium chlorite, feldspar, } \\
\text { muscovite, quartz, calcite, } \\
\text { dolomite }\end{array}$ & Hydrometric station & $\begin{array}{l}\text { Suspended sediment } \\
\text { in river }\end{array}$ & $\begin{array}{l}\text { Bukowska-Jania } \\
2007\end{array}$ \\
\hline $\begin{array}{l}\text { Amphibolite, chlorite, dolomite, } \\
\text { feldspar, mica }\end{array}$ & Southern part & Proglacial sediments & $\begin{array}{l}\text { Kabala and Zapart, } \\
2012\end{array}$ \\
\hline $\begin{array}{l}\text { Quartz, quartz-feldspar or quartz- } \\
\text { mica aggregates, quartzites and } \\
\text { quartzose schists, chlorite schists, } \\
\text { mica schists, marbles, quartzite } \\
\text { conglomerates }\end{array}$ & $\begin{array}{l}\text { Glacier portal at } \\
\text { Kvisla }\end{array}$ & $\begin{array}{l}\text { Pebbles glaciofluvially } \\
\text { deposited }\end{array}$ & $\begin{array}{l}\text { Kowalska and } \\
\text { Soroka, } 2008\end{array}$ \\
\hline $\begin{array}{l}\text { Quartz, quartz-feldspar or quartz- } \\
\text { mica aggregates, quartzites and } \\
\text { quartzose schists, chlorite schists, } \\
\text { marbles, quartzite conglomerates, } \\
\text { amphibolites, gneisses }\end{array}$ & $\begin{array}{l}\text { Subglacial outflows } \\
\text { central part (vicinity } \\
\text { of New and Black } \\
\text { spring) }\end{array}$ & $\begin{array}{l}\text { Pebbles glaciofluvially } \\
\text { deposited }\end{array}$ & $\begin{array}{l}\text { Kowalska and } \\
\text { Soroka, } 2008\end{array}$ \\
\hline $\begin{array}{l}\text { Quartz-feldspar or quartz-mica } \\
\text { aggregates, quartzites and } \\
\text { quartzose schists, chlorite schists, } \\
\text { mica schists, marbles, quartzite } \\
\text { conglimerates, amphibolites }\end{array}$ & $\begin{array}{l}\text { Southern part } \\
\text { (Angell part) }\end{array}$ & $\begin{array}{l}\text { Pebbles glaciofluvially } \\
\text { deposited }\end{array}$ & $\begin{array}{l}\text { Kowalska and } \\
\text { Soroka, } 2008\end{array}$ \\
\hline
\end{tabular}


1105 Table 2. Charge balance errors of the chemical analysis for all sites in the Werenskioldbreen

1106 basin and precipitation from Hornsund station.

\begin{tabular}{|c|c|c|c|c|c|c|c|}
\hline Site & W & HRN & $\begin{array}{l}\text { Supraglacial } \\
\text { high }\end{array}$ & $\begin{array}{l}\text { Black } \\
\text { spring }\end{array}$ & Kvisla & New & HS \\
\hline Mean & $18.8 \%$ & $10.0 \%$ & $10.9 \%$ & $3.1 \%$ & $3.7 \%$ & $2.7 \%$ & $2.0 \%$ \\
\hline Min & $4.8 \%$ & $0.6 \%$ & $2.0 \%$ & $0.8 \%$ & $0.1 \%$ & $0.1 \%$ & $0.0 \%$ \\
\hline Max & $30.2 \%$ & $29.9 \%$ & $28.1 \%$ & $5.7 \%$ & $6.5 \%$ & $5.9 \%$ & $8.0 \%$ \\
\hline
\end{tabular}

1107 (HS) surface water at hydrometric station, and (W) precipitation data from hydrometric

1108 station at the Werenskioldbreen and (HRN) Polish Polar Station at Hornsund. 
1110 Table 3. Amount of precipitation and its chemistry. Samples were collected close to the 1111 Polish Polar Station in Hornsund.

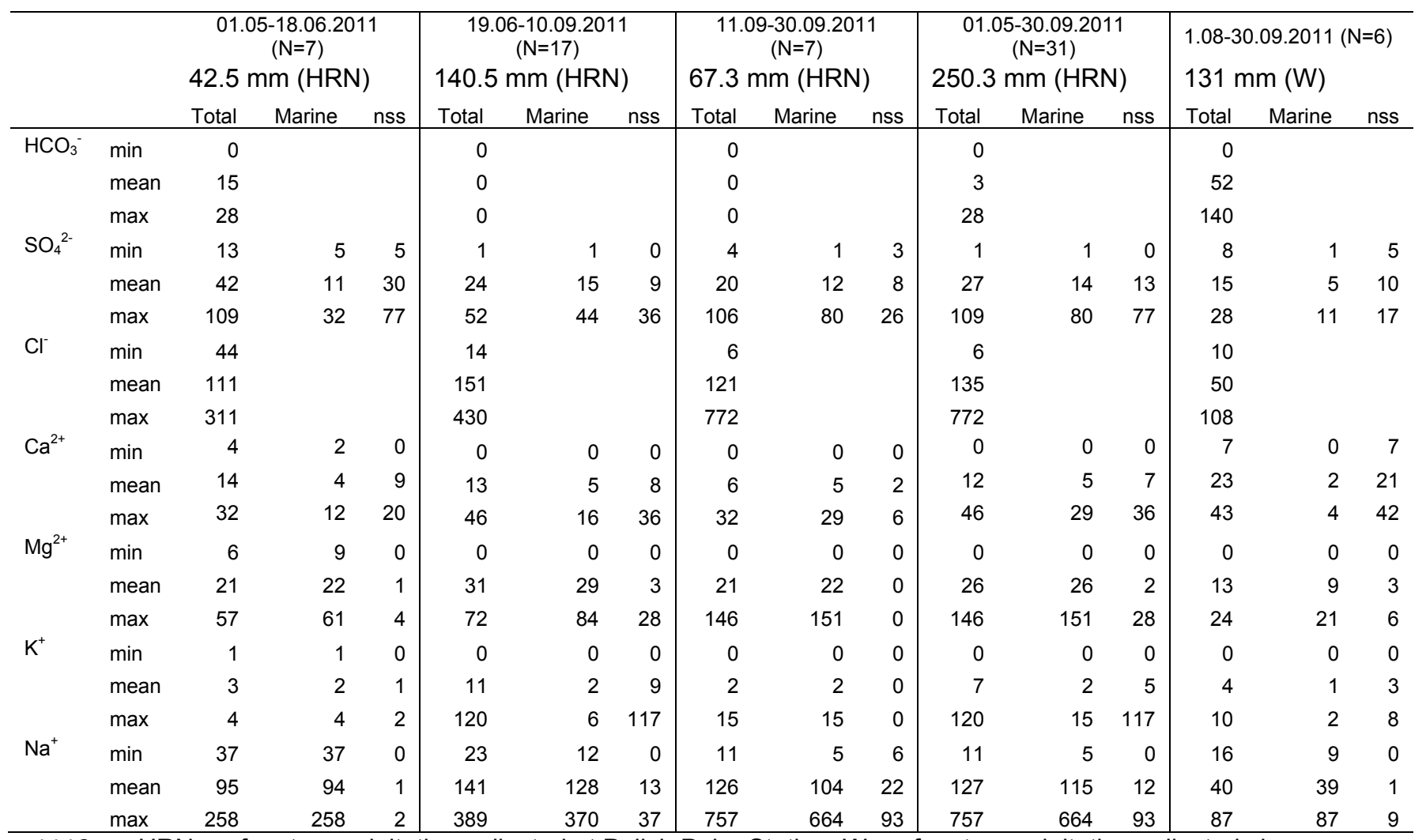

1112 HRN - refers to precipitation collected at Polish Polar Station; W - refers to precipitation collected close

1113 to hydrometric station in vicinty of Werenskioldbreen; nss - denotes non-sea-salt concentration of 1114 ions. 
1115 Table 4. Water chemistry from subglacial outflows (Black spring, New, Kvisla), the hydrometric station

1116 and supraglacial high (Supra high) in the Werenskioldbreen basin. All concentrations, excluding pH, are

1117 expressed in $\mu$ eq $\mathrm{L}^{-1}$.

\begin{tabular}{|c|c|c|c|c|c|c|c|c|c|c|c|c|c|c|c|}
\hline \multirow[b]{2}{*}{ Species } & \multicolumn{3}{|c|}{$\begin{array}{l}\text { Black spring }(\mathrm{N}=22) \\
\qquad \mathrm{pH}(\mathrm{N}=21)\end{array}$} & \multicolumn{3}{|c|}{$\begin{array}{c}\text { Dusan (N=24), pH } \\
(\mathrm{N}=20)\end{array}$} & \multicolumn{3}{|c|}{$\begin{array}{c}\text { Kvisla main }(\mathrm{N}=34) \\
\mathrm{pH}(\mathrm{N}=23), \mathrm{SiO}_{2} \\
(\mathrm{~N}=28)\end{array}$} & \multicolumn{3}{|c|}{$\begin{array}{c}\mathrm{HS}(\mathrm{N}=183), \mathrm{pH} \\
(\mathrm{N}=78), \mathrm{SiO}_{2}(\mathrm{~N}=86)\end{array}$} & \multicolumn{3}{|c|}{$\begin{array}{l}\text { Supraglacial high } \\
\qquad(\mathrm{N}=7)\end{array}$} \\
\hline & Mean & Min & Max & Mean & Min & Max & Mean & Min & Max & Mean & Min & $\operatorname{Max}$ & Mean & Min & Max \\
\hline $\mathrm{pH}$ & 9.06 & 9.59 & 8.61 & 8.84 & 9.61 & 8.30 & 8.92 & 9.78 & 8.36 & 8.26 & 9.74 & 7.44 & 5.54 & 4.95 & 7.52 \\
\hline $\mathrm{HCO}_{3}^{-}$ & 383 & 290 & 470 & 414 & 310 & 640 & 540 & 300 & 1170 & 666 & 450 & 1060 & 34 & 0 & 90 \\
\hline $\mathrm{SO}_{4}^{2-}$ & 138 & 66 & 208 & 162 & 81 & 289 & 242 & 12 & 1020 & 317 & 85 & 811 & 6 & 1 & 16 \\
\hline $\mathrm{Cl}^{-}$ & 76 & 43 & 104 & 76 & 40 & 124 & 119 & 9 & 931 & 214 & 28 & 991 & 25 & 4 & 44 \\
\hline $\mathrm{Ca}^{2+}$ & 363 & 283 & 468 & 401 & 260 & 621 & 539 & 303 & 1524 & 734 & 444 & 1107 & 42 & 9 & 94 \\
\hline $\mathrm{Mg}^{2+}$ & 89 & 56 & 123 & 101 & 54 & 201 & 219 & 20 & 860 & 263 & 87 & 598 & 5 & 0 & 17 \\
\hline $\mathrm{Na}^{+}$ & 104 & 68 & 137 & 104 & 65 & 168 & 122 & 9 & 799 & 190 & 37 & 833 & 23 & 4 & 40 \\
\hline $\mathrm{K}^{+}$ & 24 & 2 & 34 & 26 & 17 & 39 & 12 & 2 & 26 & 17 & 6 & 37 & 2 & 0 & 5 \\
\hline $\mathrm{SiO}_{2}^{\#}$ & 16 & 8 & 69 & 15 & 2 & 45 & 10 & 2 & 30 & 10 & 2 & 34 & b.d. & b.d. & b.d. \\
\hline
\end{tabular}

1118 b.d. - below detection; \# - calculation of mean $\mathrm{SiO}_{2}$ includes also $\mathrm{SiO}_{2}$ below detection limit by assuming concentration at level $75 \%$

1119 detection limit.

1120 
1121 Table 5. Water chemistry in different periods of the ablation season at the hydrometric station

1122 in the Werenskioldbreen basin. All concentrations, excluding $\mathrm{pH}$, are in $\mu \mathrm{eq} \mathrm{L}^{-1}$.

\begin{tabular}{|c|c|c|c|c|c|c|c|c|c|}
\hline \multirow[b]{2}{*}{ Species } & \multicolumn{3}{|c|}{$\begin{array}{l}\text { HS early melt } \\
\qquad(\mathrm{N}=57)\end{array}$} & \multicolumn{3}{|c|}{$\begin{array}{l}\text { HS peak }(\mathrm{N}=100) \\
\mathrm{pH}(\mathrm{N}=52), \mathrm{SiO}_{2} \\
(\mathrm{~N}=60)\end{array}$} & \multicolumn{3}{|c|}{$\begin{array}{c}\text { HS end } \\
\text { season( } N=26)\end{array}$} \\
\hline & Mean & Min & Max & Mean & Min & Max & Mean & Min & Max \\
\hline $\mathrm{pH}$ & n.m. & n.m. & n.m. & 8.38 & 9.36 & 7.96 & 8.08 & 9.74 & 7.44 \\
\hline $\mathrm{HCO}_{3}^{-}$ & 704 & 480 & 890 & 626 & 475 & 900 & 738 & 450 & 1060 \\
\hline $\mathrm{SO}_{4}^{2-}$ & 444 & 253 & 725 & 208 & 85 & 366 & 454 & 287 & 811 \\
\hline $\mathrm{Cl}^{-}$ & 361 & 152 & 991 & 168 & 28 & 385 & 68 & 31 & 113 \\
\hline $\mathrm{Ca}^{2+}$ & 844 & 558 & 1107 & 654 & 444 & 1084 & 799 & 558 & 1068 \\
\hline $\mathrm{Mg}^{2+}$ & 375 & 243 & 598 & 186 & 87 & 297 & 314 & 182 & 549 \\
\hline $\mathrm{Na}^{+}$ & 310 & 146 & 833 & 148 & 37 & 320 & 92 & 47 & 155 \\
\hline $\mathrm{K}^{+}$ & 16 & 6 & 37 & 17 & 9 & 34 & 21 & 11 & 35 \\
\hline $\mathrm{SiO}_{2}^{\#}$ & n.m. & n.m. & n.m. & 10 & 2 & 34 & 11 & 2 & 33 \\
\hline
\end{tabular}

1123

n.m. - not measured; ${ }^{\#}$ - calculation of mean $\mathrm{SiO}_{2}$ includes also $\mathrm{SiO}_{2}$ below detection limit by

1124 assuming concentration at level $75 \%$ detection limit.

1125 
1126 Table 6. Mean daily fluxes of dissolved constituents expressed in $\mathrm{kg} \mathrm{day}^{-1} \mathrm{~km}^{-2}$ and mean daily

1127 discharge in $\mathrm{m}^{3}$ day $^{-1}$ at the hydrometric station during the ablation season.

\begin{tabular}{llllllllllllllll}
\hline $\begin{array}{l}\text { Season } \\
\text { part }\end{array}$ & $\begin{array}{l}\text { Number } \\
\text { of days } \\
\text { sampled }\end{array}$ & $\mathrm{Q}^{\#}$ & $\mathrm{HCO}_{3}^{-}$ & $* \mathrm{SO}_{4}^{2-}$ & $\mathrm{SO}_{4}^{2-}$ & $* \mathrm{Ca}^{2+}$ & $* \mathrm{Mg}^{2+}$ & $* \mathrm{Na}^{+}$ & $\mathrm{Na}^{+}$ & $* \mathrm{~K}^{+}$ & $\mathrm{K}^{+}$ & $\mathrm{Cl}^{-}$ & $\mathrm{SiO}_{2}$ & $\mathrm{TDS}^{\# \#}$ \\
\hline $\begin{array}{l}\text { Early } \\
\text { ablation }\end{array}$ & 31 & 2.16 & 181 & 81 & 88 & 70 & 15 & 1 & 27 & 1 & 2 & 49 & n.m. & 347 \\
$\begin{array}{l}\text { Peak } \\
\text { flow }\end{array}$ & 54 & 8.81 & 659 & 158 & 173 & 224 & 32 & 4 & 59 & 9 & 12 & 103 & 10 & 1097 \\
$\begin{array}{l}\text { Late } \\
\text { ablation }\end{array}$ & 14 & 6.72 & 593 & 282 & 287 & 210 & 48 & 10 & 28 & 10 & 11 & 32 & 9 & 1163 \\
Total & 99 & 7.12 & 566 & 194 & 208 & 202 & 37 & 4 & 57 & 7 & 9 & 99 & 8 & 1018 \\
\hline
\end{tabular}

1128 n.m. - not measured; ${ }^{\#}$ discharge data are available from May 23rd to September 30th 2011,

1129 sum of dissolved solids fluxes corrected for marine input, bicarbonates and dissolved silica.

1130 
1131 Table 7. Runoff, sum of precipitation, ablation rate and solute yields corrected and

1132 uncorrected for marine input at the hydrometric station and solute load delivered with

1133 precipitation in 2011 in the Werenskioldbreen basin. Denudation rates were calculated based

1134 on: (DW) discharge-weighted concentrations (Hodson et al., 2000; Yde et al., 2014), (MC)

1135 mean daily concentrations. Chemical denudation is calculated for entire ablation season

1136 23.05-30.09 2011 when discharge data were available. $\left(^{\#}\right)$ the cationic denudation rate (CDR).

1137

\begin{tabular}{|c|c|c|c|c|c|c|c|c|c|c|c|c|c|c|}
\hline $\begin{array}{c}\text { Type of } \\
\text { solute load }\end{array}$ & Note & 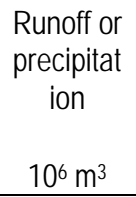 & $\begin{array}{l}\text { Ablation } \\
10^{6} \mathrm{~m}^{3}\end{array}$ & $\begin{array}{c}\text { Specific } \\
\text { runoff or } \\
\text { precipitation } \\
\text { m }\end{array}$ & $\mathrm{HCO}_{3}^{-}$ & $\mathrm{SO}_{4}{ }^{2-}$ & $\begin{array}{l}\mathrm{Ca}^{2+} \\
\mu \mathrm{eq} \\
\end{array}$ & $\mathrm{Mg}^{2+}$ & $\mathrm{Na}^{+}$ & $\mathrm{K}^{+}$ & $\mathrm{Cl}^{-}$ & $\begin{array}{r}\text { Chemical } \\
\text { precipi } \\
\mathrm{t} \mathrm{km}^{-2} \mathrm{a}^{-1}\end{array}$ & $\begin{array}{l}\text { Idation or } \\
n \text { load } \\
\text { meq }^{+} m^{-2} \\
a^{-1}\end{array}$ & $\begin{array}{c}\mathrm{CWl}^{\#} \\
\text { meq m}{ }^{-3} \\
\mathrm{a}^{-1}\end{array}$ \\
\hline $\begin{array}{c}\text { Entire } \\
\text { corrected }\end{array}$ & DW & 80.6 & 49.8 & 1.83 & 637 & 238 & 667 & 181 & 14 & 14 & n.a. ${ }^{*}$ & 121.9 & 1601 & 876 \\
\hline $\begin{array}{c}\text { Entire } \\
\text { corrected }\end{array}$ & $\mathrm{MC}$ & 80.6 & 49.8 & 1.83 & 665 & 289 & 722 & 217 & 13 & 13 & n.a.* & 132.2 & 1762 & 964 \\
\hline $\begin{array}{c}\text { Entire } \\
\text { uncorrected }\end{array}$ & DW & 80.6 & 49.8 & 1.83 & 637 & 253 & 673 & 209 & 135 & 17 & 146 & 138.8 & 1888 & 1034 \\
\hline $\begin{array}{c}\text { Entire } \\
\text { uncorrected }\end{array}$ & MC & 80.6 & 49.8 & 1.83 & 665 & 310 & 729 & 256 & 179 & 17 & 200 & 155.3 & 2157 & 1181 \\
\hline Precipitation & MC & 14.1 & n.a. & 0.32 & 3 & 27 & 12 & 26 & 127 & 7 & 135 & 2.7 & 49 & n/a \\
\hline
\end{tabular}

* - $\mathrm{Cl}$ - is absent because ion concentrations are corrected for a sea salts

based on the marine ratio.

1138

1139 
1140 Table 8. Simple linear regression equations between major ions in glacial river water at the

1141 hydrometric station and in subglacial outflows of the Werenskioldbreen basin.

\begin{tabular}{|c|c|c|c|}
\hline Ion association & $\begin{array}{l}\text { Hydrometric station } \\
\text { early ablation }(\mathrm{N}=57)\end{array}$ & $\begin{array}{l}\text { Hydrometric station } \\
\text { peak flow }(\mathrm{N}=100)\end{array}$ & $\begin{array}{l}\text { Hydrometric station1/34te } \\
\text { ablation }(\mathrm{N}=26)\end{array}$ \\
\hline $\mathrm{HCO}_{3}{ }^{-}$vs. ${ }^{*} \mathrm{SO}_{4}{ }^{2-}$ & $\begin{array}{c}y=447+0.63^{\star} x \\
(r=0.81, p<0.001)\end{array}$ & $\begin{array}{c}y=439+0.98^{\star} x \\
(r=0.76, p<0.001)\end{array}$ & $\begin{array}{c}y=271+1.05 * 143 \\
(r=0.92, p<0.001)\end{array}$ \\
\hline $\begin{array}{c}{ }^{*} \mathrm{Ca}^{2+}+{ }^{*} \mathrm{Mg}^{2+} \mathrm{Vs} \\
{ }^{*} \mathrm{SO}_{4}{ }^{2-}\end{array}$ & $\begin{array}{c}y=430+1.74^{\star} x \\
(r=0.97, p<0.01)\end{array}$ & $\begin{array}{c}y=418+2.00^{\star} x \\
(r=0.83, p<0.001)\end{array}$ & $\begin{array}{r}1144 \\
y=368+1.63^{*} x \\
(r=0.91, p<0.001)\end{array}$ \\
\hline $\begin{array}{c}{ }^{*} \mathrm{Ca}^{2+}+{ }^{*} \mathrm{Mg}^{2+} \mathrm{vs} \\
\mathrm{HCO}_{3}{ }^{-}\end{array}$ & $\begin{array}{c}y=-352+2.11^{*} x \\
(r=0.92 ; p<0.01)\end{array}$ & $\begin{array}{c}y=-213+1.62^{*} x \\
(r=0.87, p<0.001)\end{array}$ & $\begin{array}{c}y=65+1.40^{\star} x \\
(r=0.88, p<0.001)\end{array}$ \\
\hline $\mathrm{HCO}_{3}{ }^{-}$vs. ${ }^{*} \mathrm{SO}_{4}{ }^{2-}$ & $\begin{array}{c}\text { Black spring }(\mathrm{N}=22) \\
y=270+0.86^{\star} \mathrm{x} \\
(\mathrm{r}=0.68, p<0.001)\end{array}$ & $\begin{array}{c}\text { Dusan outflow }(\mathrm{N}=24) \\
y=213+1.30^{\star} x ; \\
(\mathrm{r}=0.87, p<0.001)\end{array}$ & $\begin{array}{l}\text { Kvisla main }(\mathrm{N}=34) \\
\mathrm{y}=280+1.13^{\star} \mathrm{x} \\
(\mathrm{r}=0.92, p<0.001)\end{array}$ \\
\hline $\begin{array}{c}{ }^{*} \mathrm{Ca}^{2+}+{ }^{*} \mathrm{Mg}^{2+} \mathrm{vs} . \\
\mathrm{SO}_{4}{ }^{2-}\end{array}$ & $\begin{array}{c}y=257+1.36^{\star} x \\
(r=0.75, p<0.001)\end{array}$ & $\begin{array}{c}y=181+1.96^{\star} x \\
(r=0.89, p<0.001)\end{array}$ & $\begin{array}{c}y=208+2.27^{\star} x \\
(r=0.95, p<0.001)\end{array}$ \\
\hline $\begin{array}{c}{ }^{*} \mathrm{Ca}^{2+}+{ }^{*} \mathrm{Mg}^{2+} \mathrm{vs} \\
\mathrm{HCO}_{3}{ }^{-}\end{array}$ & $\begin{array}{c}y=15+1.10^{\star} x \\
(r=0.76, p<0.001)\end{array}$ & $\begin{array}{c}y=-83+1.37^{\star} x \\
(r=0.93, p<0.001)\end{array}$ & $\begin{array}{c}y=290+1.89^{\star} x \\
(r=0.98, p<0.01)\end{array}$ \\
\hline
\end{tabular}


1147

1148

1149

1150

1151

1152

1153

1154

1155

1156

1157

1158

1159

1160

1161

1162

1163

1164

1165

1166

1167

\section{Figures captions}

Fig. 1. Location of study sites in the Werenskioldbreen basin in 2011, modified from an orthophoto map from 2011 (Norsk Polar Institute, http://toposvalbard.npolar.no/): 1 - Kvisla, 2 - Dusan outflow, 3 - Black spring, 4 - hydrometric station. Black triangles show supraglacial high streams flowing into the moulins.

Fig. 2. Seasonal variations in water chemistry, discharge and ablation rate in the Werenskioldbreen basin: A) concentrations of $\mathrm{HCO}_{3}{ }^{-}, \mathrm{SO}_{4}{ }^{2-}$ and $\mathrm{Ca}^{2+}$; B) concentrations of $\mathrm{Na}^{+}, \mathrm{Cl}^{-}, \mathrm{K}^{+}$and $\mathrm{Mg}^{2+} ; \mathrm{C}$ ) discharge at the hydrometric station, precipitation in Hornsund (Bania and Wawrzyniak, 2011a, b, c, d, e; Majchrowska and Małarzewski, 2011) and the ablation rate on Werenskioldbreen.

Fig. 3. The Piper diagram for water chemistry in the Werenskioldbreen basin.

Fig. 4. Concentrations of $\mathrm{A}) \mathrm{Na}^{+}$and $\left.\mathrm{B}\right) \mathrm{Cl}^{-}$vs. discharge during the entire ablation season at the hydrometric station in the Werenskioldbreen basin. Dotted circle shows the increase of concentration of $\mathrm{Na}^{+}$and $\mathrm{Cl}^{-}$caused by the snowmelt.

Fig. 5. Dissolved constituents vs. discharge during the entire ablation season at hydrometric station in the Werenskioldbreen basin: A) $\left.* \mathrm{Ca}^{2+} ; \mathrm{B}\right) * \mathrm{Mg}^{2+} ;$ C) Sulfate mass fraction (SMF). Fig. 6. Ion associations at hydrometric station during three periods of the ablation season: early ablation (12 May - 18 June 2011), peak flow (19 June -10 September 2011) and late ablation (11 September -25 September 2011), and in the subglacial outflows of Black spring, Kvisla and New: A) $* \mathrm{Ca}^{2+}+* \mathrm{Mg}^{2+}$ vs. $* \mathrm{SO}_{4}{ }^{2-}$, B) $\mathrm{HCO}_{3}{ }^{-}$vs. $\left.* \mathrm{SO}_{4}{ }^{2-}, \mathrm{C}\right) * \mathrm{Ca}^{2+}+* \mathrm{Mg}^{2+}$ vs. $\mathrm{HCO}_{3}{ }^{-}$. 
Figure 1

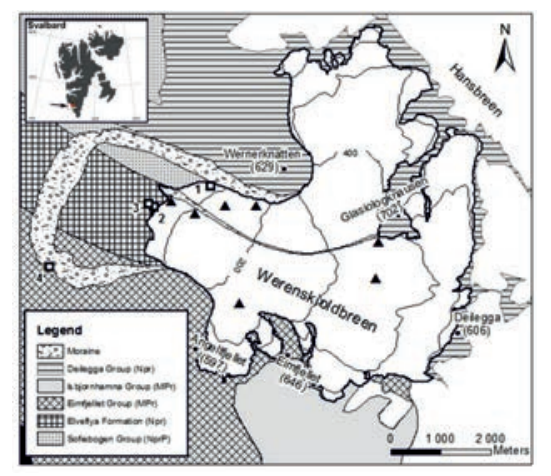


Figure 2
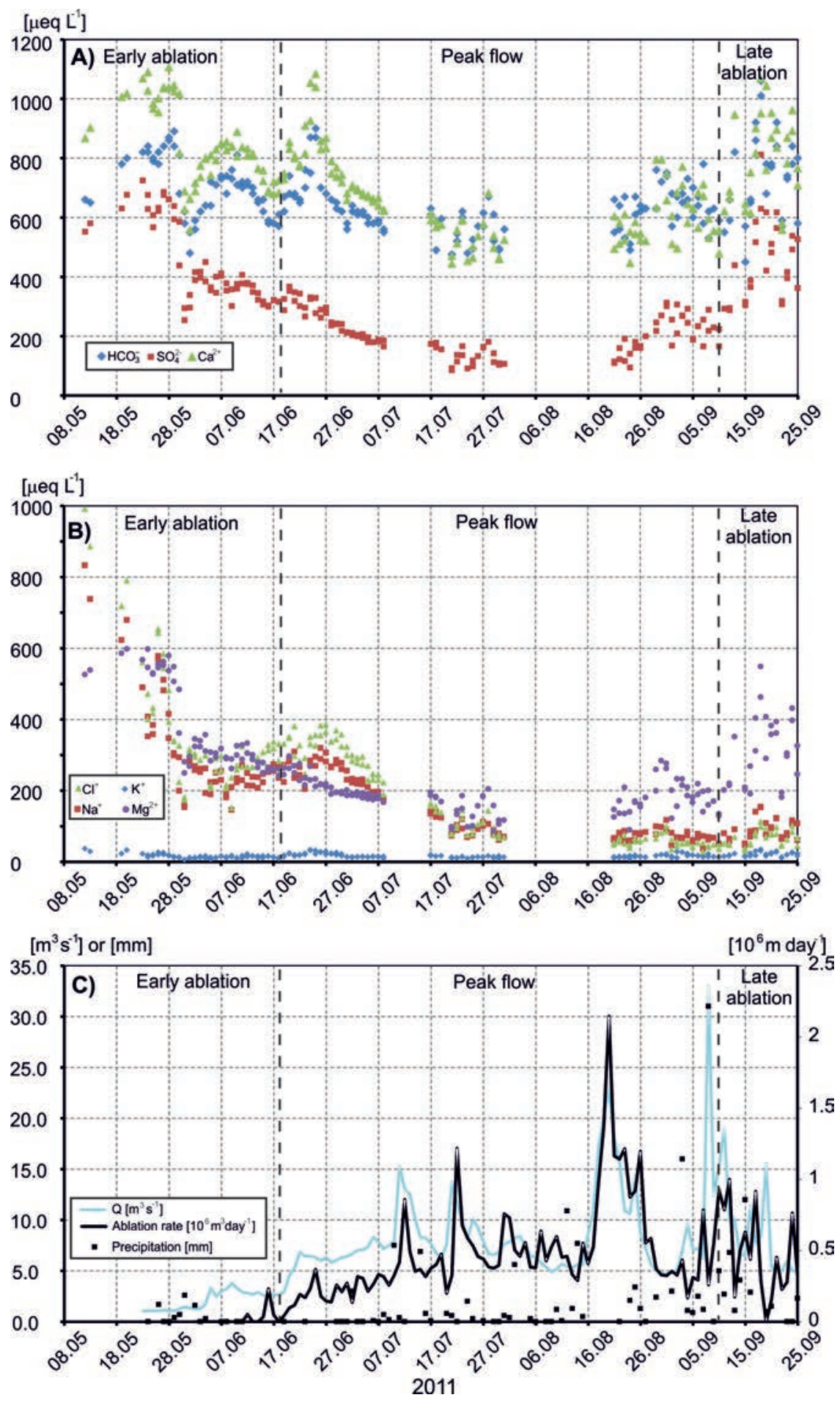
Figure 3

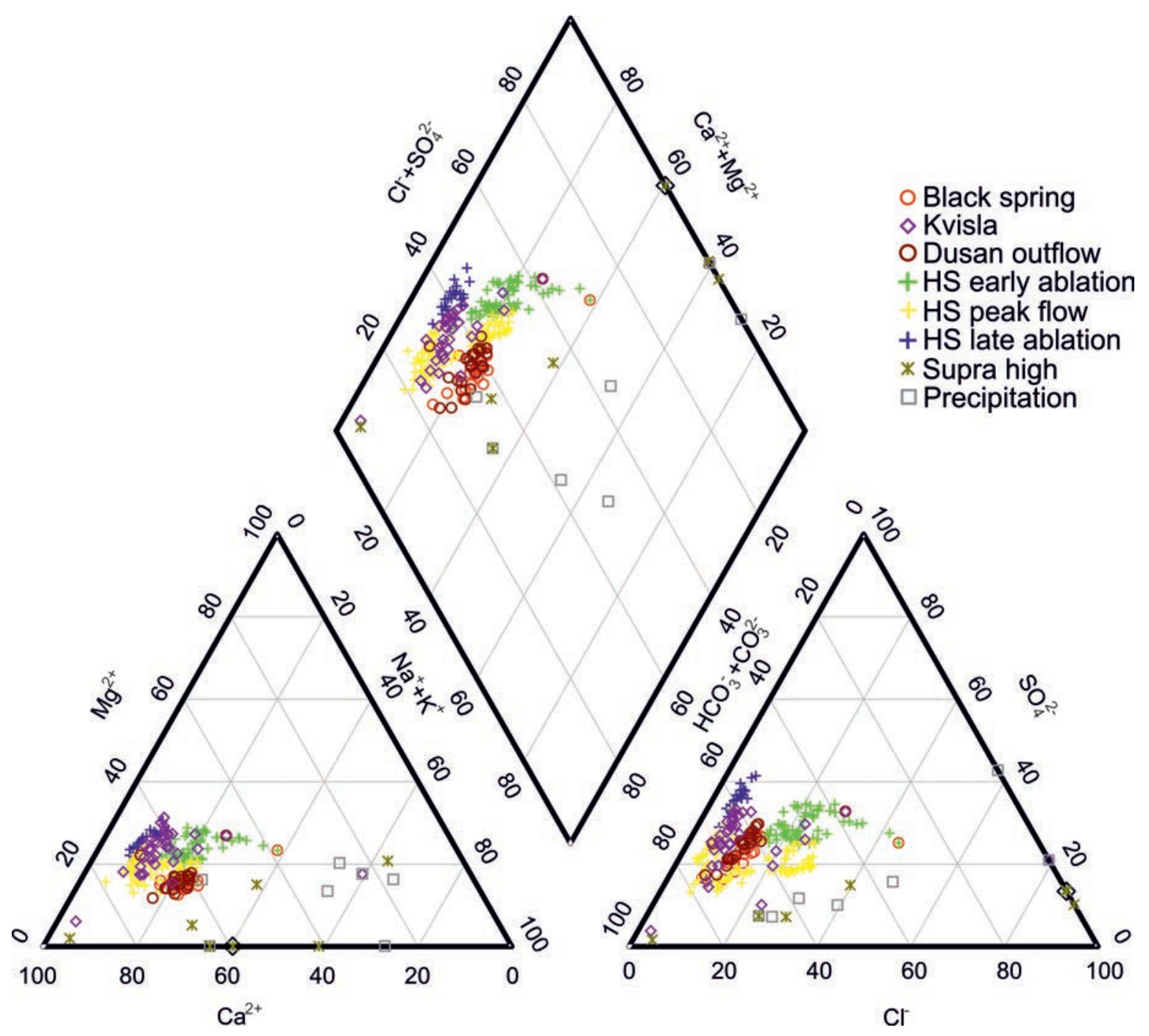


Figure 4
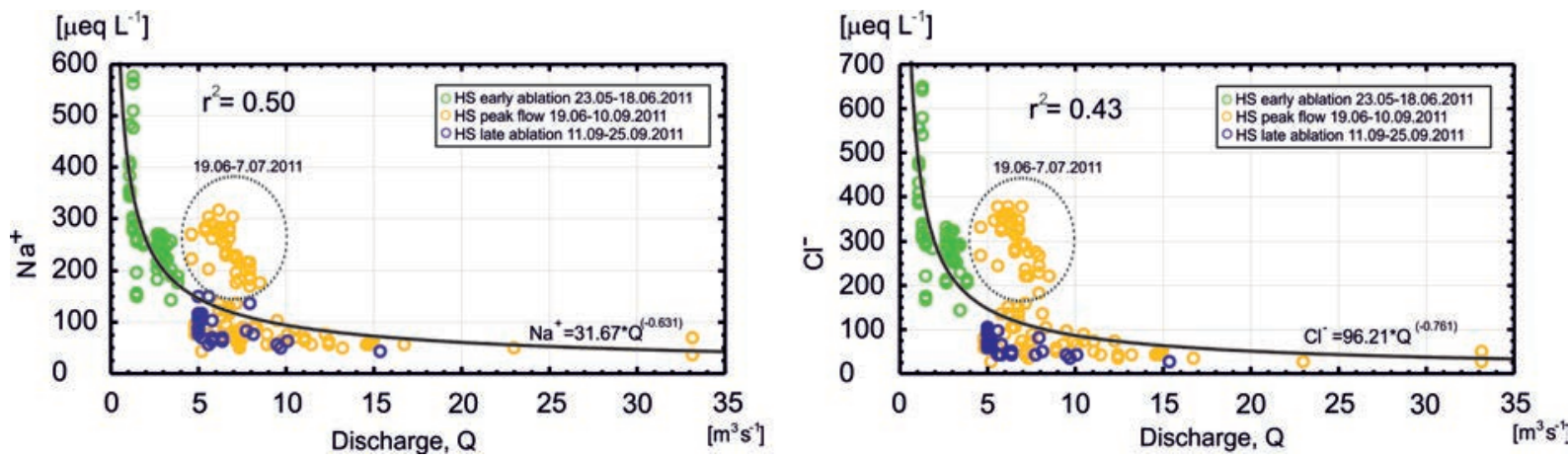
Figure 5
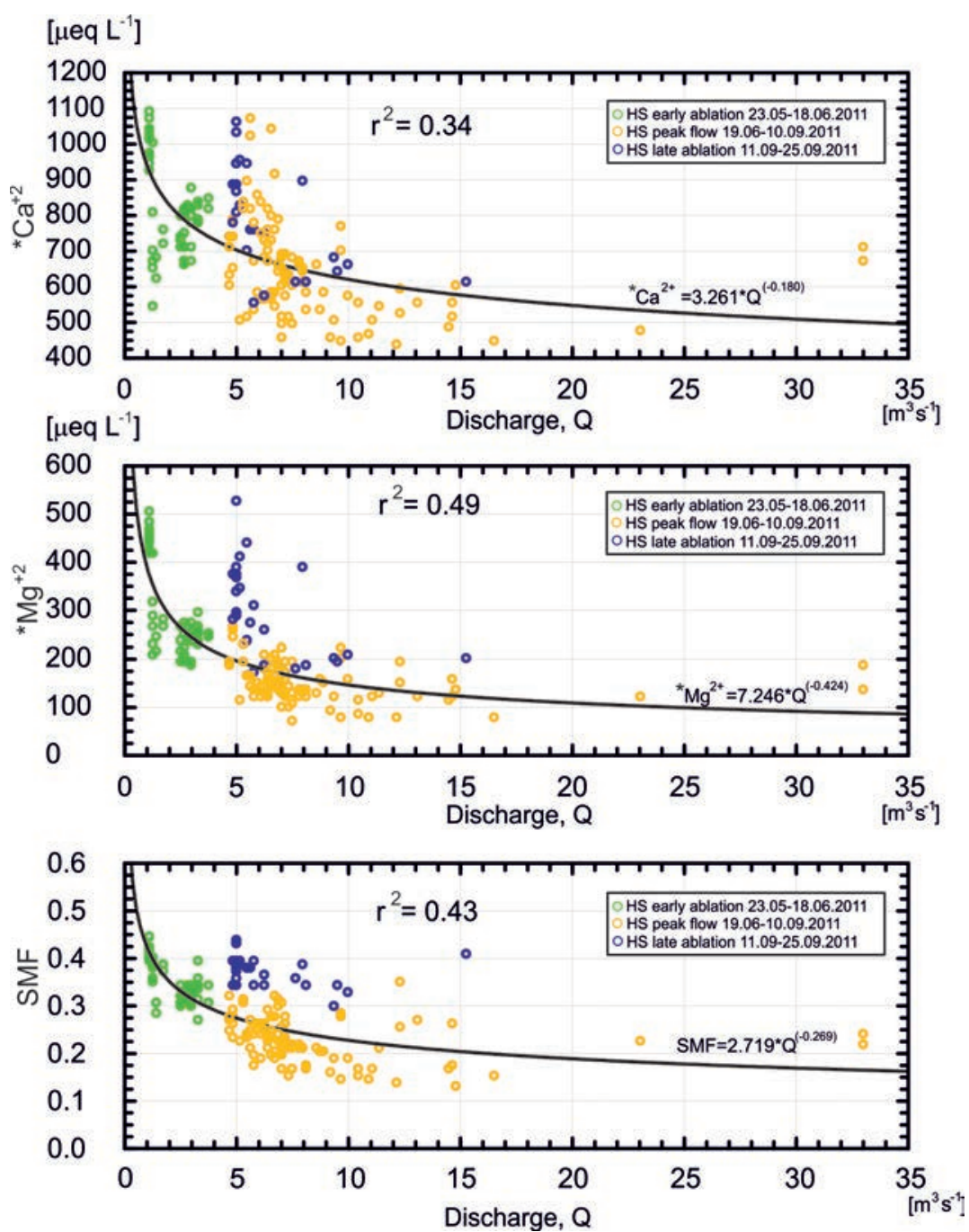
Figure 6

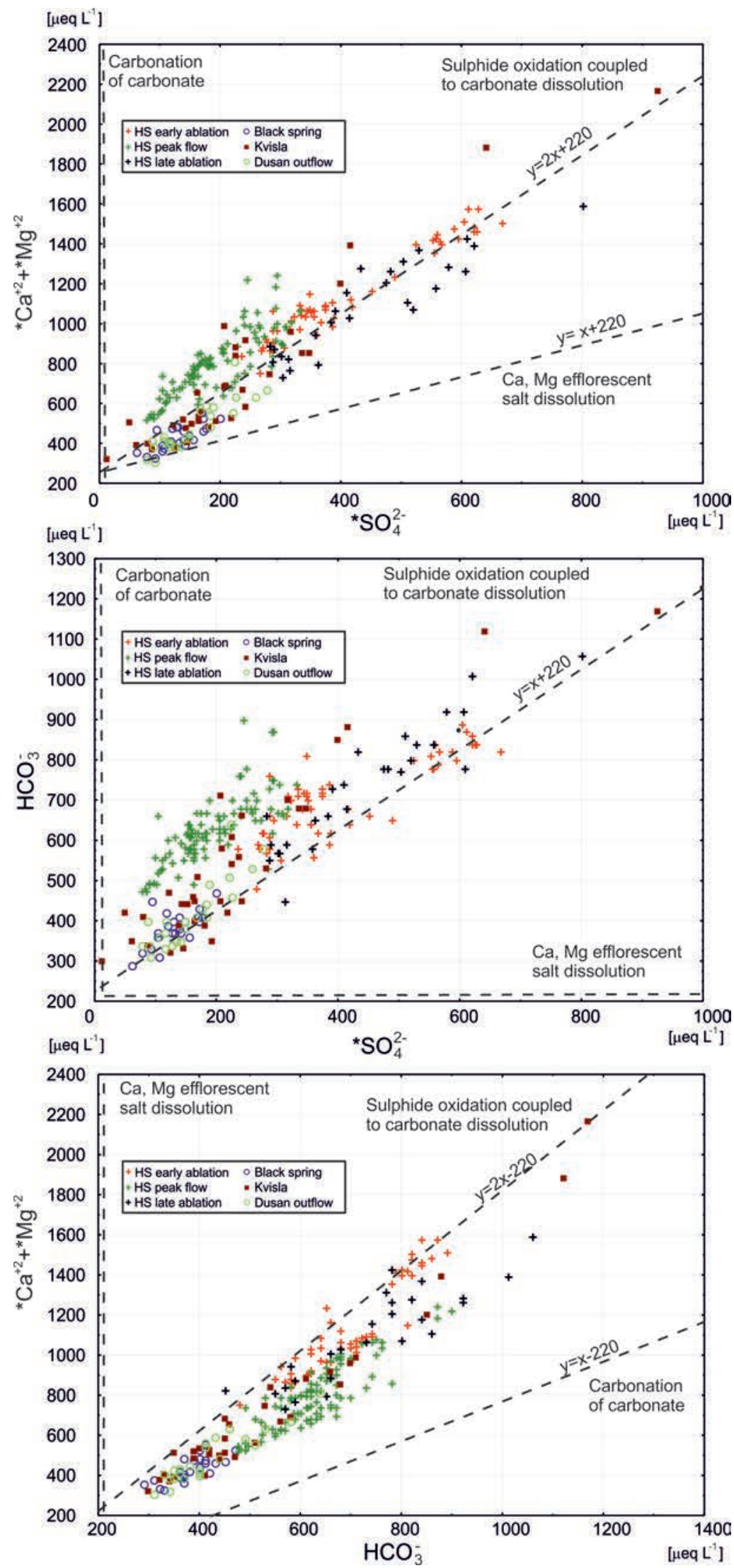

